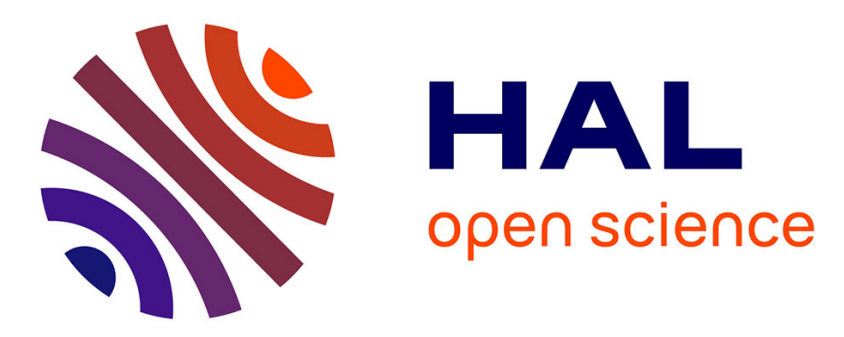

\title{
Last millennium climate variability of the varved Lake Jeinimeni geochemical record from NE Chilean Patagonia
}

\author{
N Fagel, P Pedreros, D Alvarez, W Tylmann, O Namur, A. C. da Silva, P \\ Jana, A Araneda, I Billy, Sabine Schmidt, et al.
}

\section{To cite this version:}

N Fagel, P Pedreros, D Alvarez, W Tylmann, O Namur, et al.. Last millennium climate variability of the varved Lake Jeinimeni geochemical record from NE Chilean Patagonia. Quaternary Science Reviews, 2021, 269, pp.107134. 10.1016/j.quascirev.2021.107134 . hal-03337100

\section{HAL Id: hal-03337100 https://hal.science/hal-03337100}

Submitted on 14 Nov 2021

HAL is a multi-disciplinary open access archive for the deposit and dissemination of scientific research documents, whether they are published or not. The documents may come from teaching and research institutions in France or abroad, or from public or private research centers.
L'archive ouverte pluridisciplinaire HAL, est destinée au dépôt et à la diffusion de documents scientifiques de niveau recherche, publiés ou non, émanant des établissements d'enseignement et de recherche français ou étrangers, des laboratoires publics ou privés.

\section{(ㅇ)(1) $\$$}

Distributed under a Creative Commons Attribution - NonCommercial - NoDerivatives $\mid 4.0$ 
2

3

4

5

8

9

10

11

12

13

14

15

16

17

18

19

20

21

22

\section{Last millennium climate variability of the varved Lake Jeinimeni geochemical record from NE Chilean Patagonia}

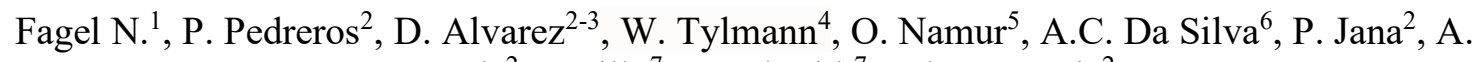
Araneda $^{2}$, I. Billy ${ }^{7}$, S. Schmidt ${ }^{7}$ and R. Urrutia ${ }^{2}$

1. Université de Liège, AGEs - Argiles, Géochimie et Environnements sédimentaires, Department of Geology, 4000 Liège, Belgium

2. University of Concepcion, Faculty of Environmental Sciences and EULA - Chile

Environmental Sciences Centre, Concepcion, Chile

3. Universidad Santo Tomás, Facultad de Ciencias, Concepcion, Chile.

4. University of Gdansk, Faculty of Oceanography and Geography, Poland

5. KU Leuven University, Department of Earth and Planetary Sciences, 3001 Heverlee, Belgium

6. Université de Liège, Sedimentary Petrology. Department of Geology, 4000 Liège Belgium

7. Université de Bordeaux, UMR Environnements et Paléoenvironnements Océaniques et Continentaux, France

Contact e-mail address: nathalie.fagel@uliege.be

\section{Highlights}

- Lake Jeinimeni sediments in NE Patagonia records a detrital varved sequence over at least $750 \mathrm{yr}$, from $\sim \mathrm{AD} 1250$ to 2008

- Seasonal clastic supplies are related to spring temperature and snowmelt discharge

- Correlation to instrumental record supports that varve thickness in Lake Jeinimeni is a proxy for precipitation

- The thicker (thinner) clastic varves characterize dry (wet) periods

- Few thick layers record exceptional erosive conditions responsible for major floods

\section{Abstract (288 words)}

Paleoclimate studies in Patagonia show a high Holocene climate variability, strongly controlled by the intensity and latitudinal position of the Southern Westerly Winds. In this study, environmental and climate variability, and in particular winter precipitation, was reconstructed over the last centuries through sedimentological and geochemical analyses of a core from Lake Jeinimeni in North East Patagonia. Visual description, X-ray radiographies and thin section 
observations point to finely laminated sediments, made by fine sands and light brown clayey silts forming an annual deposition (varves) occasionally interrupted by two Hudson volcanorelated tephras and 15 pluri-millimetre to pluri-centimetre coarser sandy to gravely layers. Varve counting confirmed by ${ }^{210} \mathrm{~Pb}$ and ${ }^{137} \mathrm{Cs}$ indicates a detrital sequence of at least $750 \mathrm{yr}$. Based on a correlation with local meteorological data for the 1930-1988AD interval, varve thickness and statistical treatment of XRF geochemical data give information on transport pathway and sedimentary deposit conditions. The sandy laminae correspond to the deposition of high sedimentary load delivered by austral spring snowmelt whereas the clayey silt laminae result of particle settling in the water column during low hydrodynamical conditions. Thicker varves observed in dry conditions underline the importance of aeolian transport in sedimentary deposition. During locally dry and windy summer, the wind may erode and remobilise the sedimentary deposits along the lake margins. The sandy and gravely layers record massive erosional events due to proximal watershed perturbation driven by climatic or tectonic mechanisms. The clastic varves of Lake Jeinimeni document environmental decadal to multidecadal variability in East Patagonia over the last centuries. The more pronounced sediment transition around AD 1750 is consistent with the inception of the Little Ice Age-type event, in agreement with North Patagonian paleoclimate reconstructions derived from glacier advances, lacustrine varve thickness and tree-ring records.

\section{Keywords:}

Lacustrine sediment, clastic varves, climate variability, XRF-core scanner, Late Holocene

\section{Introduction}

Holocene climate variability at the southernmost tip of South America is strongly controlled by the latitudinal position and intensity of the Southern Westerlies Winds (SWW; Markgraf 1993, Gilli et al., 2005, Garreaud et al., 2009; among others). SWW are associated to storm 
tracks bringing heavy rainfalls (Trenberth 1991). At present, these winds bring precipitation over the western site of southern South America with a peak in precipitation around latitudes $52^{\circ}-53^{\circ} \mathrm{S}$ and generate arid conditions on the eastern side of the Andes (Garreaud, et al., 2013). The SWW are persistent throughout the year with limited seasonal latitudinal variations (Garreaud 2009). In austral winter (JJA), the SWW expand with a southerly position $\left(\sim 55^{\circ} \mathrm{S}\right)$ whereas it contracts in austral summer (DJF) in an northerly position $\left(\sim 50^{\circ} \mathrm{S}\right)$. During austral winters, the SWW extends, providing rainfall to central Chile $\left(33^{\circ}-40^{\circ} \mathrm{S}\right)$ (Markgraf 1993; Garreaud 2007). The SWW expansion is associated with a decrease of the wind velocity, especially in its core zone in southernmost Chile $\left(50^{\circ}-55^{\circ} \mathrm{S}\right)$ (Lamy et al. 2001, 2010). On the other hand, the wind speed increases in austral summer due to the contraction of the SWW (Garreaud 2009).

Located within the mid-latitude $30-60^{\circ} \mathrm{S}$ belt, Patagonia is located between two main circulation systems, i.e. the Intertropical Convergence Zone (ITCZ) to the North and the Antarctic Convergence Zone (ACZ) to the South. Garreaud et al. (2013) emphasized that summer precipitation anomalies over Patagonia are correlated with Antarctic Oscillation (AAO) mode whereas winter anomalies are rather linked with El Niño-Southern Oscillation (ENSO)-controlled SWW anomalies over the SE Pacific (Montecinos and Aceituno 2003).

For the last decades, paleoclimate studies in Patagonia emphasized high temporal climate variability over the late glacial (Gilli et al., 2005; Markgraf et al., 1992, 2013; Mayr et al., 2013; Moreno et al., 2001), the Holocene (e.g., Markgraf et al., 1993, 2003; Moreno et al., 2009; Moy et al., 2009, 2011; Villa-Martínez et al., 2012; Zolitschka et al., 2019) and the last millennium (e.g., Mayr et al., 2013; Moy et al., 2008; Sepulveda et al., 2009; Schimpf et al., 2011; Villalba 1994). Among the main variability, precipitation variations, derived from different paleoclimate proxies (e.g., pollen and terrestrial indexes, charcoal content, magnetic susceptibility signal, mineralogical or geochemical ratios) and archives (e.g., marine or lacustrine sediments, ice 
cores, tree rings) were mainly used to reconstruct the evolution of SWW, in terms of wind intensity and latitudinal position over the Holocene (e.g., Villalba 1994; Villa-Martínez and Moreno 2007; Moy et al., 2008; Moreno et al., 2009; Lamy et al., 2010; Alvarez et al., 2015). According to vegetation distributions, divergent scenarios have been proposed for climate changes in Patagonia $\left(44-49^{\circ} \mathrm{S}\right)$. Markgraf et al. (2003) suggested a northwards migration of SSW during the middle Holocene until they reached their modern position in the late Holocene (Markgraf et al., 1992). This latitudinal migration would be responsible for the Late Holocene higher climate variability in Patagonia (Markgraf et al., 2013). Villa-Martinez et al. (2012) rather suggested changes in the strength of the SWW at millennial and multi-millennial timescales since the last glaciation with no major latitudinal shifts.

For the last millennium however, the variability of the SWW remains less documented and poorly understood. It is particularly the case for the two major climate events, namely the Medieval Climate Anomaly (MCA) and the Little Ice Age (LIA) (e.g., Moy et al., 2008). The LIA was an aparently centuries-long climate state occurring around ca. AD 1400-1800 (Bradley et al., 2003) or AD1300-1850 (Masson-Delmotte et al., 2013; Mann et al., 2009; Neukom et al., 2019). It contrasts with a warm temperature period ranging between AD800 and AD1200, defined as the MCA (Neukom et al., 2019). In particular for those events, the strong variability revealed, for instance, in fjord sedimentary sequences from northwest Patagonia (Bertrand et al., 2014; Sepulveda et al., 2009) is inconsistent with paleoclimate reconstructions (Neukom et al., 2010). Those reconstructions display unequal and sparse proxy data distribution, especially for the Southern Hemisphere and for the last millennium (Neukom et al., 2010). However, paleoclimate reconstructions show poor coherency during these supposed cold and warm epochs over the past $2 \mathrm{kyr}$ (Neukom et al., 2019). The LIA period, in particular, fails to present a spatio-temporal coherency with the coldest temperature ranging from the fifteen to the midnineteen century according to the site location. Inconsistent results have also been derived from 
113 the interpretation of different paleoclimate continental and marine Patagonian archives

114 (Bertrand et al., 2014). As underlined by Moy et al. (2008), the scarcity of accurately-dated, 115 continuous and unequivocally climate-related archives limit our understanding of recent and 116 past Patagonian climate. In addition, the SWW fluctuations have mainly been studied in a 117 latitudinal context, without taking account the influence of the Andes along a W-E longitudinal 118 transect. Some interpretations of Westerlies fluctuations made on the western side of the Andes 119 are indeed located in areas close to the eastern side generating contradictory results with 120 previous studies (Lamy et al., 2010).

121 Therefore, this study aims to document environmental and climate variability, mainly related to the SWW influence, in a North Eastern Patagonian sector over the last millennium. The Lake Jeinimeni location provides a unique laminated record that contributes to better understanding the variability of SWW-related precipitation over the last centuries. Both sedimentological (i.e., varve thickness) and geochemical data (represented by the two first principal components) are correlated with local meteorological data (i.e., temperature, precipitation) to identify the main drivers of the sedimentation and further to follow their temporal evolution. The main scientific questions we would like to address in this manuscript are the following ones:

(1) Does the sediment record any correlation with any meteorological variable associated with the SWW-related precipitation? (2) If any, how does it vary over the last millennium? (3) Is there any change in the sediment record associated with the manifestation of the MCA and the LIA in the region? (4) Is the climate evolution deduced from Lake Jeinimeni record consistent with the paleoclimate records available on a regional scale?

\section{Study area}

The Lake Jeinimeni (latitude $46.5^{\circ} \mathrm{S} 72^{\circ} 0 \mathrm{~W}$, Fig. 1) is located in the Aysen XI region of Chile (Fig. 1A), at $\sim 50 \mathrm{~km}$ south of Chile Chico (Fig. 1B), close to the border with Argentina. 
138 The geology of the Aysen region (Pankhurst et al., 1999) comprises three main units reported

139 in Figure 1C: 1) the Meso-Cenozoic North Patagonian batholith (hornblende-biotite 140 granodiorites and tonalities); (2) the Devonian-Carboniferous Eastern Andean metamorphic 141 complex (clastic metasediments) and; (3) the Late Jurassic Ibanez Formation (volcanic rocks, 142 dacite and rhyolite, andesitic lavas and sedimentary intercalations). Some Eocene and Mio143 Pliocene continental flood basalts and Pliocene granodiorites also outcrop South West of Chile 144 Chico (De la Cruz et al., 2003). Quaternary alluvial and fluvio-glacial deposits with some 145 intercalations of volcanoclastic deposits occur along the rivers. The topography of the Aysen 146 area includes the southern extension of the Andean Cordillera, which is characterized by eternal 147 snow, numerous glacial valleys and is covered by two major mountain ice fields (Glasser et al., 148 2008). Patagonian glaciers are highly sensitive to climate variability and have expanded and 149 contracted several times during the Quaternary (Glasser et al., 2012). They react to latitudinal 150 migrations of the SWW that control precipitation (Trenbeth 1991, Lamy et al., 2010) and/or to 151 temperature changes (e.g., Moreno et al., 2001; Heusser et al., 2006; Villa-Martinez et al., 2012). Major ice discharges are evidenced by moraine distributions at $1.1 \mathrm{Ma}, 140-150 \mathrm{ka}$ (MIS6), 16-23 ka (MIS2) (Hein et al., 2009). The Lago General Carrera/Buenos Aires is the regional largest moraine-damned lake (see Fig. 1B - Glasser et al., 2012). It was formed during the final glacier retreat (ca $12.8 \mathrm{ka}$ ), as the Patagonian Ice Sheet decoupled into the Northern and Southern Patagonian Ice Sheets and drainage routes opened up towards the Pacific Ocean 157 (Turner et al., 2005).

Located at $\sim 150 \mathrm{~km}$ East of the Northern ice field (altitude $700-2500 \mathrm{~m}, \sim 4.000 \mathrm{~km}^{2}$ ), the 159 Lake Jeinimeni watershed (Fig. 1B) corresponds to a mountainous system with steep slopes and 160 small foothills cut by rivers and numerous streams. The lake altitude is 840 masl and in terms 161 of its dimensions has a surface area of $0.045 \mathrm{~km}^{2}$, and the deepest point registered by this study 162 was of $82 \mathrm{~m}$. The Lake Jeinimeni with its narrow and elongated morphology belongs to the 
glacial Lago General Carrera/Buenos Aires watershed (Hein et al., 2010). Its origin is related to glacial outlet that allows the drainage of the Northern Patagonian icefield and is controlled by the bedrock topography (Glasser et al., 2008).

Present day climate of the Lake Jeinimeni watershed is cold and humid, with a steppe environment characterized by a sharp orographic eastward decrease in precipitation (e.g., Escobar et al., 1992). According to the closest meteorological station (i.e., Chile Chico station $46.58^{\circ} \mathrm{S}, 71.69^{\circ} \mathrm{W}$, altitude $306 \mathrm{~m}$, see location on Fig. 1B), the annual average temperature is low, it oscillates between 7 and $9^{\circ} \mathrm{C}$ with a wide range between the coldest month $\left(3^{\circ} \mathrm{C}\right)$ and the warmest one $\left(14^{\circ} \mathrm{C}\right)$ (data reported in CONAF 2017). Likewise, the annual precipitation is low ( $<500 \mathrm{~mm}$; New et al., 2002). The Chile Chico reports a yearly average of cumulated precipitation of $293 \mathrm{~mm} \pm 101$ for the 1960-2014 interval (data from Instituto de Investigaciones Agropecuarias INIA - Hepp et al., 2018), with strong seasonal contrast between dry austral summer and wet austral winter. Such seasonal variability is mainly controlled by latitudinal migration and strength of the SWW. The measured wind velocity displays an annual average of 18 knots ( 7 to 25 knots) with a dominant $\mathrm{W}$ direction. The fastest wind speeds are observed during austral summer that are locally dry (data 2019 in Direccion General de Aeronautica Civil - DGAC 2020). Located on the eastern side of the Andes, the austral winter precipitation in the Lake Jeinimeni area fall mainly as snow above $1000 \mathrm{~m}$ (Villalba et al., 1997). The accumulation of snow reaches up to 6 to $10 \mathrm{~m}$ each year. The lake Jeinimeni is bordered by hills that are part of the called "Cordon La Gloria" (Fig. 1C), reaching altitudes above $1800 \mathrm{~m}$. The main stream (i.e., La Gloria) that descends from the northwest carries a large amount of sediments that are deposited during spring in the valley between the Lake Verde and the Lake Jeinimeni. (Fig. 1C). These sediments can interrupt the flow of the Verde River, leading to a rise of the river and lake levels, eventually flooding the adjacent terranes (Henriquez and Alvear 1987). The sedimentary transport is characterized by a strong seasonal 
control, evidenced by river discharge. Located at the outlet of the Lake Jeinimeni, the annual flow of the Jeinimeni River (Fig. 1D), measured monthly at the Chile Chico station since 2019 (reported in Direccion General de Aguas - https://dga.mop.gob.cl/), displays a first increase related to precipitation in autumn (April-May), followed by a second one associated to snow melting in spring (Sept-Nov).

The vegetation is characterized by a steppe ecotone. The catchment $\left(212 \mathrm{~km}^{2}\right)$ is covered by patches of Andean temperate deciduous forest leaded by Nothofagus pumilio and Berberis ilicifolia and temperate Mediterranean (so-called "Patagonian steppe" in Markgraf et al., 2007) dominated by Poaceae herbs (Fetusca pallescens) and Apiacea (Mulinum spinosum) (Luebert and Pliscoff, 2006). The upper limit of the forest being located between 1200 and $1400 \mathrm{~m}$, the low availability of vegetal cover up to the summit line favours erosion of the slopes and runoff (CONAF 2017).

Due to the combination of young landscapes modelled by glacier and rivers and cool climate associated with the Northern Patagonia Ice Field, the soils in the study area are weakly developed, dominated by entisols on fluvial terraces, inceptisols on the surfaces exposed after ice retreat and some histosols (Pfeiffer et al., 2010). The study area is at the Southern limit of andisol development. Weakly developed in the River Baker drainage Basin $(27 \%,<0.6 \mathrm{~m}$ of volcanic cover), andisols are for instance absent south of the Lake General Carrera, in Chile Chico (Vandekerkhove et al., 2015). There is no evidence of active volcanism in the area that corresponds to the "Patagonian volcanic gap". The closest active volcano (Hudson Volcano) is the southernmost volcano of the Southern Volcanic Zone (Stern 2004), located $130 \mathrm{~km}$ to the north west of the study area. The ashes from the Hudson Quaternary explosive eruptions at 3.6 kyr BP and 6.7 kyr BP may have reached the study area (Naranjo and Stern 1998) but according to Naranjo et al. (1993) recent eruptions in AD 1971 and 1991 did not deposit ash. In term of tectonic, Lake Jeinimeni is located at the south eastern side of the main structural strike-slip 
213 lineaments in North Patagonia (i.e., Liquiñe-Ofqui Fault Zone, Río Mañihuales Fault, Thomson

214 2002), responsible for crustal intraplate earthquakes (Vanneste et al., 2018). However, an

215 additional tectonic influence is possible since a fault crossing the lake was recently inferred by

216 Encinas et al. (2018).

\section{Material and methods}

\subsection{Sediment core}

A $161 \mathrm{~cm}$ core (LJe14B, S46 50 '42”, W72 $\left.00^{\prime} 47^{\prime \prime}\right)$ was taken in the eastern end of the lake

(Fig. 1D), using an Uwitec ${ }^{\circledR}$ gravity corer at a water depth of $61 \mathrm{~m}$ in January 2014. A coring was attempted in a more distal site but it was not successful due to strong winds, frequent in austral summer.

The core was opened longitudinally and the archive half-core section was described and photographed. The sediment core is characterized by a fine sedimentary texture interrupted by several coarser layers named event and numbered from E1 to E8 according to increasing depth.

As an exception the lowest part of the sediment core $(155-161 \mathrm{~cm})$ does not present any lamination. This section may be disturbed by coring and has not been further taken in account in the interpretation. The archive section was measured by non-destructive methods that include magnetic susceptibility, X-Ray imaging system (SCOPIX) and XRF core scaner. Magnetic susceptibility (MS) was measured with a Bartington ${ }^{\circledR}$ magnetic susceptibility meter MS2E point sensor with a $5 \mathrm{~mm}$ sampling interval. The working section was entirely subsampled utilizing aluminium boxes ( $25 \mathrm{~cm}$ length $\mathrm{x} 4 \mathrm{~cm}$ wide $\mathrm{x} 1.5 \mathrm{~cm}$ deep) that were slowly pushed into the cleaned sediment surface and was extruded with a knife, after a $180^{\circ}$ rotation of the core section. The $25 \mathrm{~cm}$ long boxes were used to prepare the large thin section. The remaining sediment material was subsampled at $2.5 \mathrm{~cm}$ for loss-on-ignition (LOI) measurements. 
$\mathrm{C} / \mathrm{N}$ ratio were measured at $1 \mathrm{~cm}$ sampling resolution for the upper $15 \mathrm{~cm}$ then at $10 \mathrm{~cm}$. (Lab. Oceanology and AGEs, Université de Liège). After a $\mathrm{HCl}$ pre-treatment to remove any carbonates, $\sim 30 \mathrm{mg}$ of sediment sample powder was analysed for $\mathrm{C} / \mathrm{N}$ ratio and $\delta^{13} \mathrm{C}$ with a Fisons ${ }^{\circledR}$ NA $1500 \mathrm{NC}$ elemental analyser coupled with an Optima IR-Mass Spectrometer (Hedges and Stern 1984).

LOI was measured at $60^{\circ} \mathrm{C}$ overnight for water content, at $550^{\circ} \mathrm{C}$ for $4 \mathrm{~h}$ organic matter and then at $950^{\circ} \mathrm{C}$ for $2 \mathrm{~h}$ for carbonates (following the technique described by Heiri et al. 2001). $\mathrm{X}$-ray diffraction (XRD) analyses were done at 5 to $10 \mathrm{~cm}$ sampling resolution. The sediment samples were dried at $40^{\circ} \mathrm{C}$ and crushed with an agate mortar to 150 microns. The powder was transferred into a sample holder according to the backside method (Moore and Reynolds 1997). XRD patterns were measured with a Bruker ${ }^{\circledR}$ D8- Advance Eco diffractometer (Copper K $\alpha$ radiance, $\lambda=1.5418 \AA, \mathrm{V}=40 \mathrm{KV}, \mathrm{I}=25 \mathrm{~mA}$ ) coupled with a linear Lynxeye Xe energy dispersive detector. The non-oriented powder was scanned from 2 to $70^{\circ} 2 \theta$ with a step size of $0.009^{\circ} 2 \theta$, and a time per step of 0.5 seconds. Semi-quantitative mineral abundance was estimated from the intensity of a diagnostic peak multiplied by a corrective factor defined by Cook et al. (1975) and Boski et al. (1998). The maximum intensity of the diffraction band at $4.04 \AA$ was used to estimate the amorphous content in the sediments due to the occurrence of biogenic silica, volcanic glasses and/or organic matter (see more information in Fagel et al., 2017). The XRD mineralogy of the event layers was also done for comparison purposes with the background sediment.

In addition, the grain-size distribution was measured by a laser Malvern ${ }^{\circledR}$ Mastersizer 2000 diffraction particle analyser (Chemical Department, Université de Liège) on a selection of 8 samples from the coarse event layers evidenced by macroscopic description. The bulk sediment samples were sieved at $2 \mathrm{~mm}$, dispersed in deionised water and introduced into the Hydro 
of laser beam obscuration, homogenised and disaggregated with a $2000 \mathrm{rpm}$ stirrer and $20 \%$ of ultrasonic waves. The analysis was repeated at least 3 times to ensure the reproducibility of the analysis. The results are reported as frequency distribution curves (Sperazza et al., 2004). Scanning Electron Microscope (SEM/EDX) and Electron Microprobe (EMPA) analyses have been performed on 2 coarser and darker layers (E1 and E2) observed in the upper $10 \mathrm{~cm}$ of LJe14B. The dried bulk sediment was sieved at 105-425 microns, then separated by liquid density separation using bromoform and the glass-rich light fraction was mounted in epoxy resin. SEM observations and EDX analyses were performed with a Quanta 650-F QEMSCAN (FEI) equipped with a Bruker $6 \backslash 30 \mathrm{~mm}^{2}$ EDX detector at the Aachen University (Germany). We used an acceleration voltage of $15 \mathrm{kV}$ and a working distance of $10 \mathrm{~mm}$. Photos were taken with a dwell time of $10 \mu$ s and EDX spectra were collected from 0 to $10 \mathrm{keV}$. Quantitative EMPA analyses of glass beads were performed with a Cameca SX 5 with 5 WDS spectrometers at the Ruhr-Universität Bochum (Germany). We used a beam with an acceleration voltage of $15 \mathrm{kV}$, a current of $8 \mathrm{nA}$ and, for most analyses, a spot size of $10 \mu \mathrm{m}$. For EMPA calibration, the following standards were used for K $\alpha$ X-ray: Na on albite, $\mathrm{Mg}$ on olivine-SC_233, Al, Si, $\mathrm{K}$ on orthoclase, $\mathrm{Ca}$ on wollastonite, $\mathrm{P}$ on apatite, $\mathrm{Ti}$ on rutile, $\mathrm{Fe}$ on hematite and $\mathrm{Mn}$ on rhodonite. The accuracy and reproducibility of the EMPA analyses were controlled by the repeated analyses $(n=15)$ of the international glass standard A99 (average sum of oxides $98.66 \% \pm 0.53)$

\section{$\underline{\text { 3.3. Laminae counting and geochronological analyses }}$}

Sediment micro-structure was detailed by thin section observations under the microscope according to the procol described in Żarczyński et al. (2018). The sedimentary material was subsampled from the $25 \mathrm{~cm}$-long aluminium boxes for large thin sections of 10 to $12.5 \mathrm{x} 2 \mathrm{x}$ $1.5 \mathrm{~cm}$. The sediment was first shock-frozen in liquid nitrogen and, then freeze-dried at University of Liege. The next impregnation step with epoxy resin was done in specialized 
laboratories. Two $12.5 \mathrm{~cm}$-long thin sections were produced for the upper $25 \mathrm{~cm}$ at EPOC,

289 Univ. Bordeaux (France). Fifteen $10 \mathrm{~cm}$-long (with $2 \mathrm{~cm}$ overlapping) were produced between 25 and $150 \mathrm{~cm}$ at MK factory in Potsdam (Germany).

291 All thin sections were scanned in polarized light with a resolution of 2400 DPI using a flatbed scanner and polarizing foils to identify, to count and to measure the thickness of the laminations. Axio Imager A2 (Zeiss, Germany) microscope was used to investigate thin sections under nonpolarized and polarized light at the University of Gdanks.

After establishing a preliminary model of laminae succession representing annual sedimentation, couplets of laminae were counted on scanned images of thin sections. Counting was done twice by a single person for the whole sediment core with additional third counting restricted only to difficult core sections, in order to avoid possible misinterpretation. Finally, unclear couplets of laminae were included in the chronology as half a year and the counting uncertainty was increased by \pm 0.5 years, respectively. Following this step, the uncertainty was cumulatively summed along the chronology.

The age model was corroborated by applying ${ }^{210} \mathrm{~Pb},{ }^{226} \mathrm{Ra},{ }^{232} \mathrm{Th}$ and ${ }^{137} \mathrm{Cs}$ data that were measured in the upper $16 \mathrm{~cm}$ of core LJe14b at EPOC (Univ. Bordeaux, France) using a lowbackground and high-efficiency well-type gamma detector. The analyses were performed on 1 cm-thick samples $(\sim 1.5 \mathrm{~g}$ of dried sediment) retrieved from the archive section. The excess ${ }^{210} \mathrm{~Pb}\left({ }^{210} \mathrm{~Pb} b_{\mathrm{xs}}\right)$ activities were calculated as the difference of the measured ${ }^{210} \mathrm{~Pb}$ and ${ }^{226} \mathrm{Ra}$. Decrease with depth of ${ }^{210} \mathrm{~Pb}_{\mathrm{xs}}$ is then converted into age by applying the Constant Flux/Constant Sedimentation (CF/CS) model according to Appleby and Oldfield (1978). They were calibrated by the Southern Hemisphere calibration curve SHCal13 (Hogg et al., 3112013 ) and corrected by a reservoir age of 540 years estimated from the average $\mathrm{C} / \mathrm{N}$ ratio of the 312 core (16.7\% at.) using the relationship established by Bertrand et al. (2012) for North 
313 Patagonian lakes. The Clam 2.2 code (Blaauw 2010a, b) in the open source software R was

314 used to perform an age-depth model by combining ${ }^{137} \mathrm{Cs}$, excess ${ }^{210} \mathrm{~Pb}$ and ${ }^{14} \mathrm{C}$ data.

$315 \quad$ 3.4. Elemental core scanning

316 An X-Ray imaging system composed with an X-ray tube and a linear X-Ray camera has

317 been used at the EPOC laboratory (Univ. De Bordeaux, France) to obtain an X-Ray image of

318 the core, and gray-scale level of the sediment (data SCOPIX). Both measurements were

319 performed on the archive half-core section. Sediment core scanning was done at a resolution of

$3202 \mathrm{~mm}$ an Avaatech XRF core scanner (Richter et al., 2006; Rothwell et al., 2006) equipped with

321 a Rh tube on the Al boxes at the EPOC laboratory (Univ. Bordeaux, France). The XRF core

322 scanning was done at 10,30 and 50KV and 15, 20 and 25 s exposure time, respectively. Fifteen

323 elements have been measured: Al, Si, S, K, Ca, Ti, Mn, Fe, Zn, Br, Rb, Sr, Y, Zr and Ba. Semi-

324 quantitative concentration profiles of the elements are plotted along the sediment core based on

325 the variations of their peak areas on the XRF core scanner spectra.

$326 \quad$ 3.5. Statistic section

327 Geochemical elements obtained from XRF core scanner were analysed through Principal 328 Component Analysis (PCA). PCA produces new sets of variables, called Principal Components 329 (PCs) and only the PCs with eigenvalues $>1$ explain significantly the total variance of the 330 dataset. Moreover, all the elements do not significantly contribute to the PCs and only those 331 characterized by a communality values $\geq 0.5$ are usually retained for PCA (Davis 2002).

332 Geochemical data series are compared to monthly-averaged temperature and precipitation 333 records from the local Chile Chico meteorological station, which began reporting in AD 1960 334 (Hepp et al., 2018). The calibration time window was extended down to AD 1930 by using the 335 climate reconstruction CRU_TS 4.03 (Harris and Jones 2020), retrieved for the geographical 336 coordinates $47^{\circ} .00$ to $46.40^{\circ}$ latitude $\mathrm{S}$ and $72.20-71.51^{\circ}$ longitude W (http://climexp.knmi.nl). 337 The retained calibration interval spans from AD1930 to AD1988. The oldest CRU_TS 4.03 
data for AD 1900-1930 interval was not retained for calibration since Elbert et al. (2012) have emphasized before AD 1930 a poor quality of the reanalysis in the area. The youngest interval 1991-2014 AD, corresponding to the upper $5 \mathrm{~cm}$ of LJe14B record, has not been take into consideration due to the presence of a coarse event E1 $(4.5-5 \mathrm{~cm})$. Below the E1 event, the LJe14 data were linearly interpolated in order to compare the core proxies with yearly-averaged meteorological data. For the comparison of meteorological data and sedimentological proxies, we applied moving average filters of three, five and seven- years for the period 1930-1988 AD. Pearson coefficients and $\mathrm{p}$ value $(\mathrm{p}<0.05)$ were used to evaluate the strength of the relationships for determining the main environmental controlling factors. All statistical analyses were performed in R (R Development Core Team 2016) using the psych and corrplot packages (Revelle 2017, Wei and Simko 2017).

\section{Results}

\subsection{Core sedimentology and mineralogy}

The core image, grey-scale level (SCOPIX), Al count (XRF core scanner), magnetic susceptibility, water and organic matter contents (LOI60 and LOI550, respectively) and geochemistry of organic matter $\left(\mathrm{C} / \mathrm{N}\right.$ and $\left.\delta^{13} \mathrm{C}\right)$ measured on the core LJe14B are presented in

Fig. 2. The sediments retrieved in core LJe14B are mainly detrital and inorganic, with a water content ranging between 11 and $43 \%$ (average $34 \pm 6 \%$ ) and an averaged organic matter abundance of $1.6 \pm 0.3 \%\left(1.3<\mathrm{LOI}\right.$ at $\left.550^{\circ} \mathrm{C}<4.2 \%\right)$ (Fig. 2). The sediments of Lake Jeinimeni are made by finely laminated light brown clayey silt (fine silt mode at $3 \mu \mathrm{m}$ ) with a few remarkable layers, referred to event layer $(\mathrm{E})$ and described in the next section. $\mathrm{C} / \mathrm{N}$ and $\delta^{13} \mathrm{C}$ values are relatively constant, with averages of $16.7 \pm 3.8$ (atomic ratio) and $-26.2 \pm 0.4 \%$, respectively. The average high $\mathrm{C} / \mathrm{N}$ ratio indicates an important contribution of reworked organic matter from the watershed (Meyers and Teranes 2001). Sparse benthic diatoms are observed in the thin sections, with Eunotia, Cymbella, Nitzschia, Encyonema and Rhopalodia 
as the main representative genera. Central planktonic frustules are also detected in the upper part of the core (4-6 cm). Diatoms represent an estimated abundance $<1 \%$, they are indicative of a marshy-like environment (I. Israde Alcantara, personal communication 2/2019).

The mineralogical assemblages of core LJe14B are quite constant through the core (SM Fig. 1). Clay minerals $(36 \pm 4 \%)$ and quartz $(31 \pm 3 \%)$ are the dominant phases, associated with similar abundance of $\mathrm{K}$-feldspars $(13 \pm 3 \%)$ and plagioclase $(12 \pm 2 \%)$, mica $(8 \pm 1 \%)$ and traces of chlorite and amphibole $(<2 \%)$. The total amorphous phases average $11.8 \pm 1.9 \%$ of the core mineralogy, with a maximum of $16 \%$ in the two tephra layers. It is made by organic matter content $(1.3-4.2 \%)$, diatoms $(\sim 1 \%)$, tephra glasses at $4.5-5 \mathrm{~cm}$ and $7-7.5 \mathrm{~cm}$ and reworked volcanic material from the watershed.

\subsection{Laminated sediments}

The sedimentary sequence of Lake Jeinimeni in core LJe14B is made by millimetre-scale rhythmic alternations of coarse grained quartz- and feldspar-rich layers and fine grained clayey silt layers with minor organic contributions. This laminated pattern resembles clastic varves with typical particle-size differences between coarse- and fine-grained laminae deposited during spring/summer snowmelt and winter calm conditions, respectively (Sturm 1979).

The preservation quality of laminations is generally good except the sections adjacent to the event layers, where disturbances in the sediment structure appear. The base of coarse grained laminae forms sharp boundary with underlying fine grained laminae. In contrast, the contact between coarse grained and overlying fine-grained laminae is gradual and does not form a distinct boundary. Instead, a smooth fining upward is visible, which makes a reliable measurement of individual laminae (coarse $v s$. fine) thickness impossible. Thickness of laminae couplets ranges from 0.3 to $7.6 \mathrm{~mm}$, although the majority $(80 \%)$ is in the range $0.7-2.5 \mathrm{~mm}$. The averaged thickness for the entire sediment sequence is $1.54 \pm 0.89 \mathrm{~mm}$.

\subsection{Event layers}


In the upper part of the core, two darker event layers are evidenced by naked eye at $4.5-5 \mathrm{~cm}$ and 7.4-7.9 $\mathrm{cm}$ (i.e., E1 and E2, respectively) and well-marked under the microscope by sharp bases with no or minimal erosion (Fig. 2). The uppermost layer displays the highest measured magnetic susceptibility value in the core (i.e., 486 SI, in contrast with the core average of $54 \pm 36$ SI). The samples at depths of $4-5 \mathrm{~cm}$ and $7-8 \mathrm{~cm}$ are dominated by silt (69\%), yet are associated with $12-17 \%$ of sand and $14-18 \%$ of clay. They both present a fine silt mode $(8.5-9.8 \mu \mathrm{m})$, darker grey-scale values and lower Al count (Fig. 2). Similar drops are observed in the Si, K and $\mathrm{Rb}$ core profile whereas $\mathrm{Ti}, \mathrm{Ca}$ and $\mathrm{Sr}$ rather display a marked increase only at $4.5-5 \mathrm{~cm}$ (Fig. 1 and SM Fig. 2). Only the Zr profile evidences a second increase at 7-7.5 cm (SM Fig. on both E1 and E2 samples (Fig. 3). In addition, the EMPA major geochemistry of the glass shards from $\mathrm{E} 1$ corresponds to an andesite with a high $\mathrm{K}$ content (averaged abundance of $\mathrm{SiO}_{2}$ $=62.39$ wt. $\% \pm 1.07, \mathrm{~K}_{2} \mathrm{O}=2.48$ wt. $\% \pm 0.10, \mathrm{n}=9$ ).

Between 34 and $67 \mathrm{~cm}$, three pluri-centimetre event layers interrupt the laminated sedimentation: E3 from 34 to $38 \mathrm{~cm}$, E4 from 44 to $48 \mathrm{~cm}$ and E7 between 65 and $67 \mathrm{~cm}$ (Fig. 2). They are characterized by an irregular erosive base and a thinning upward graded bedding. Their grain-size corresponds to fine to medium sand with some gravels. According to the classification of Folk and Ward (1957) they are poorly to very poorly sorted, with sorting values ranging between 1.8 and 3. Samples $35-36 \mathrm{~cm}$ and $65-66 \mathrm{~cm}$ are made by $>82 \%$ of sand associated with $14 \%$ of silt and $4 \%$ of clay, with a mode at 307 and $184 \mu \mathrm{m}$, respectively. Those layers are characterized by darker colour, a marked decrease in Al count and porosity, slightly lower magnetic susceptibility, lower water content and organic matter but no change in the $\mathrm{C} / \mathrm{N}$ nor $\delta^{13} \mathrm{C}$ values (Fig. 2). The sample $44-45 \mathrm{~cm}$ presents a mode at $178 \mu \mathrm{m}$ with $32 \%$ of sand, $46 \%$ of silt and $22 \%$ of clay particles (SM Fig. 3). Note there is no significant difference in the 
413 mineral abundance of the event layers E3, E4 and E7 by comparison with the background 414 sediment (SM Fig. 1).

415 In addition to the two pluri-millimetric E1 and E2 and the three pluri-centimetre layers E3, 416 E4 and E7, twelve additional remarkable event layers have been observed under the microscope 417 within the $150 \mathrm{~cm}$ of LJe14B (Fig. 2). They correspond to two groups identified on the thin 418 sections: (1) non-erosive or representing minimal erosion only, and (2) layers of deformed 419 laminations and cracks. First group is represented by eight thin $(4-11 \mathrm{~mm})$ layers with no or 420 only minimal erosion (E5, E6, E8, E9, E12, E13, E14, E16). Low potential erosion was 421 estimated based on the contact with underlying laminae, which were not disturbed. Second group consists of four layers (E10, E11, E15, E17), which partly result from cracks and sediment deformations. It is difficult to interpret unambiguously if these layers are original sedimentation structures or artefacts related to sediment impregnation.

\subsection{Core chronology}

For the upper section of core LJe14B $(0-16 \mathrm{~cm})$, the age model was derived from ${ }^{210} \mathrm{~Pb}_{\mathrm{xs}}$ and

${ }^{137} \mathrm{Cs}$ data (Fig. 4a, data reported in Table 1). The profile of ${ }^{210} \mathrm{~Pb}$ xs displays drastic variations with low ${ }^{210} \mathrm{~Pb}_{\mathrm{xs}}$ level in the uppermost $4 \mathrm{~cm}$ (Fig. $4 \mathrm{~b}$ ). Such low activity of ${ }^{210} \mathrm{~Pb}$ in the first centimeters could be related to rapid sedimentation event, that dilutes ${ }^{210} \mathrm{~Pb}_{\mathrm{xs}}$ (e.g., Quiroz et al., 2005). This hypothesis is consistent with the occurrence of E1 event observed at $4.5-5 \mathrm{~cm}$ in LJe14B. Only the samples characterized by equivalent ${ }^{232} \mathrm{Th}$ activities $(\sim 70 \mathrm{mBq} / \mathrm{g})$ are retained (Table 1). This long-lived radionuclide is associated with the detrital fraction and then equivalent activities may indicate of rather equivalent lithological sources or proportions. The sample at $7-8 \mathrm{~cm}$ was discarded from the age model: this level was only measured to precise the shape of the ${ }^{137} \mathrm{Cs}$ peak, and the counting session was not long enough to allow a reliable determination of ${ }^{210} \mathrm{~Pb}_{\mathrm{x}}\left(\right.$ low ${ }^{229} \mathrm{Th}$ for event E2). The control points are: 1$)$ the surface age (2013 AD) and; 2) the maximum ${ }^{137} \mathrm{Cs}$ activity $(20 \mathrm{mBq} / \mathrm{g})$ observed at $8.5 \mathrm{~cm}$ (Fig. $\left.4 \mathrm{~b}\right)$ and associated 
to the most intense period of atmospheric nuclear tests fallout (Stupar et al., 2014). The ${ }^{137} \mathrm{Cs}$ 439 peak is fixed at $1965 \mathrm{AD} \pm 5 \mathrm{yr}$.

$440 \quad$ For the upper $16 \mathrm{~cm}$, ages were calculated every $2 \mathrm{~mm}$ with $95 \%$ confidence ranges assuming 441 a linear regression (Fig.4a). The Pb-Cs age model gives a mean sedimentation rate of 1.43 $\mathrm{mm} / \mathrm{yr}$ for the upper $15.5 \mathrm{~cm}$ of core LJe14B. This value is fully consistent with the average thickness of laminae couplets of $1.48 \pm 0.86 \mathrm{~mm}$ measured for the same depth interval. Moreover, there is a good consistency between laminae couplets counting and the ${ }^{210} \mathrm{~Pb} /{ }^{137} \mathrm{Cs}$ age model (Fig. 4a). Assuming an annual sedimentation, the chronology based on varvecounting is reported for the whole core in Fig. 4c. Scanned images of the thin sections were correlated with core photographs to identify gaps in the thin sections and further refine the proposed age model. In Lake Jeinimeni the uppermost $150 \mathrm{~cm}$ sedimentary sequence recovered in core LJe14B encompasses $759 \pm 62$ years (i.e., error of 8\%), from 2013 down to 1254 AD (1193 $\mathrm{AD}<$ age $<1318 \mathrm{AD})$, without taking account $15 \mathrm{~cm}$ of cumulative events (E1 to E17). The sedimentary sequence may be uncompleted due to the erosive action of the pluri-centimetre massive deposits, especially E4 and in a lesser proportion E3 and E7.

For the lower part of the core, only bulk sediment was available for radiocarbon dating as no terrestrial macroremain was found to be dated. Even taking account the reservoir correction established for the same Patagonian sector (Bertrand et al., 2012), the calibrated radiocarbon dates remain quite old (Table 2) and induce a sharp drop of the sedimentation rate between the upper part of the core $(0.16 \mathrm{~cm} / \mathrm{yr})$ and the lower part of the core $(0.03 \mathrm{~cm} / \mathrm{yr})$ (see SM Fig. 4). As such change was not supported by any lithological observation, the bulk sediment dates were discarded from the age model. Lacustrine bulk sediments may be contaminated by old "dead" carbon from the watershed (e.g., Abbott and Stafford 1996, Moy et al., 2011, Albéric et 


\section{Discussion}

\section{$\underline{5.1 .}$ Annual character of the sedimentation}

A set of observations attests for the annual character of the sedimentation retrieved in the core LJe14B. First, the annual character of the laminations is supported by a calculated significant correlation between the measured varve thickness and local meteorological data. The highest Pearson coefficient of $-0.71(\mathrm{p}<0.0001$, Table 4$)$ is obtained between austral spring (SON) precipitation and varve thickness. The coefficient is moderate but still significant between annual precipitation and varve thickness $(-0.53, \mathrm{p}<0.0001-$ Table 4$)$. The correlation is attested for the last century, i.e., from AD1930 and 1988.

Second, the number of laminae couplets observed on the thin section within the upper $16 \mathrm{~cm}$ of the LJe14B core is consistent with the ${ }^{210} \mathrm{~Pb} /{ }^{137} \mathrm{Cs}$ age model (Fig. 4a). This observation confirmed the annual character of the deposits at least for the upper core section, i.e, for the last 120 years corresponding to the age window covered by the ${ }^{210} \mathrm{~Pb}$ geochronometer.

A third argument is related to the calculated age of the two event layers observed in the uppermost $8 \mathrm{~cm}$ of core LJe14B. The ${ }^{210} \mathrm{~Pb} /{ }^{137} \mathrm{Cs}$ age model gives an age of AD 1981-1996 for the event layer E1 and 1963-1977 for event E2. Given by Clam interpolation, the best ages of AD 1988 and AD 1970 for E1 and E2, respectively, are very close to the age of the two most recent explosive eruptions of the Hudson volcano (i.e., HU 1991 AD and HU 1971 AD, Scasso and Carey 2005). The activity of the Hudson volcano started at $\sim 1 \mathrm{Ma}$ (Orihashi et al., 2004) and the Holocene stratigraphy of its fallout deposits records at least twelve more explosive eruptions. Among them the most important eruption happened in August AD 1991 (Naranjo and Stern, 1998). Another historical eruption took place in August AD 1971, when an eruptive column rose $14 \mathrm{~km}$ high, leaving a wide scale tephra fall out deposit over the region (Fuenzalida, 1976). In addition to the age consistency, the glass shards-rich content detected by SEM observations of the E1 and E2 samples (Fig. 3) confirm their volcanic origin. The 
microprobe analyses of the glass shards of the sample $4-5 \mathrm{~cm}$ gives a chemical composition similar to the signature of the Hudson eruptions, in particular with the AD 1991 eruption (Naranjo and Stern 1998) (Fig. 3).

Since the laminae couplets display the same structure under the microscope all along the core LJe14B depth, we assume that the sedimentary deposition in the lower part of the core also represents an annual character and are therefore interpreted as varves.

\subsection{Sedimentary deposit conditions}

Lake Jeinimeni sediments are mostly clastic with a very minor biogenic component. The organic matter content is relatively low, ranging between 1.3 and $4.2 \%$ (Fig. 2). Its geochemical signature, with high $\mathrm{C} / \mathrm{N}$ (mean $16.7 \pm 3.8$ atomic ratio) and very negative $\delta^{13} \mathrm{C}$ values $(-26.96$ to -25.39), reflects a mixing of lacustrine and terrestrial organic matter (Meyers and Terranes, 2001). The stable mineralogical assemblages suggest that the source of detrital supplies remains constant through time. However, changes in grain-size, observed at both microscopic and macroscopic scales, reflect different modes of sediment transportation.

The elemental data measured on core LJe14B allows to explain in further detail the sedimentation pattern (see Davies et al., 2015 for a review). In the following section the PCA scores of the main PCs (PC1, PC2) will be reported along core depth to track for lacustrine environmental variability. Among the XRF core scanner dataset, some elements (e.g., Al, Si, K, Ti and Fe) display similar trends (Fig. 2 and SM Fig. 2), and by applying a multivariate statistical analysis such as Principal Component Analysis (PCA), it is possible to disentangle the forcing mechanisms behind the temporal variability (e.g., Avsar et al., 2014). Four Principal Components (PC) were identified representing $70.3 \%$ of the total variance (Table 3 ). However, according to the communality values, the contribution of $\mathrm{Mn}(0.19)$ is lower than the other elements and was therefore removed from the analysis. After its exclusion, the four PCs explain $74.6 \%$ of the total variance, with $42.4 \%$ of the variance explained by $\mathrm{PC} 1$ and $14.8 \%$ by PC2 
513 (Table 3). PC1 is positively correlated with $\mathrm{Al}, \mathrm{Si}, \mathrm{K}, \mathrm{Ti}, \mathrm{Fe}, \mathrm{Ca}, \mathrm{Sr}$ and $\mathrm{Y}$ and negatively

514 associated with $\mathrm{S}, \mathrm{Zn}$ and $\mathrm{Ba}$. Among these elements, Al, Si, K, Ti, Fe are indicators of detrital 515 supplies. Abundant in clay minerals, micas and feldspars, they correspond to lithogenic 516 elements, geochemically stable, hosted by resistant minerals with a conservative behaviour 517 through the sedimentary cycle (Boës et al., 2011). In addition to their affinity for carbonates, $518 \mathrm{Ca}$ and $\mathrm{Sr}$ are also present in the detrital sedimentary fraction, mainly in plagioclase minerals. 519 S is often associated to organic matter (e.g., Avsar et al., 2014) that may also include metallic 520 element like Zn. PC2 explained the $14.8 \%$ of the variance and is positively associated with $\mathrm{Sr}$, $521 \mathrm{Ca}$ and negatively with $\mathrm{Rb}, \mathrm{Ba}$. In addition to biogenic component, $\mathrm{Sr}$ and $\mathrm{Ca}$ are also present 522 in detrital fraction mainly present in plagioclase feldspars (Davies et al., 2015, p. 196; Rothwell 523 and Croudace 2015, p. 63). Rb is chemically similar to K that it substitutes in K-feldspars and 524 micas (Davies et al., 2015, p. 196; Rothwell and Croudace 2015, p. 81), two minerals less easily 525 chemically-weathered than plagioclase. $\mathrm{Rb}$ is rather enriched in fine clay and silt fraction 526 (Kylander et al., 2011). In the PCA results, Ba is distributed in close proportion between PC1 527 and $\mathrm{PC} 2$. According to its ionic ratio, $\mathrm{Ba}$ may substitute $\mathrm{Ca}$ and $\mathrm{Sr}$ in plagioclase, but also $\mathrm{K}$ in 528 K-feldspars [e.g., in sanidine - cf. Cherniak (2002), Puchelt (1969-1978) cited in Rothwell and 529 Croudace (2015), page 79].

530 The measured elements by the XRF provide hints about the sediment lithologies (i.e. tephra, 531 fine clayey silt, fine to medium sand, coarse sand with some gravels). In the binary diagram 532 PC1 vs. PC2 (Fig. 5), most samples are clustered along the PC1 axis and are distributed in three 533 groups characterized by different grain sizes: (1) the highest positive values of PC1 fit with the 534 field of the fine clay-rich samples; (2) the moderate negative PC1 values range within the field 535 of the coarse sandy-rich samples; (3) the more negative PC1 values mainly correspond to the 536 field of the three pluri-centimetre thick event layers E. Such sample distribution suggests that 537 PC1 is sensitive to the hydrodynamics of the aquatic system; notably the energy of 
hydrodynamics. All the elements associated to the PC1 have a detrital origin delivered by soils reworking and/or watershed erosion of the parental sediments and rocks. The river transports fine detrital-rich supplies that settle down at the coring site during calm conditions whereas coarser material is transported during periods of higher energy hydrodynamics. In addition to this main trend observed along PC1 axis, a few samples are rather aligned along the PC2 axis. These samples correspond to the tephra layers (i.e., events E1 and E2) observed in the upper core section and some type of detrital interference by them (i.e., labelled as tephra-influenced layer on Fig. 5). In the PC1-PC2 biplot, the distribution of $\mathrm{Sr}$ and $\mathrm{Ca}$ (and $\mathrm{Zr}$ in a lesser proportion) may be influenced by the tephra layers. Such observation is consistent with the results of Unkel et al. (2010) who evidenced enrichment in $\mathrm{Zr}$ associated to $\mathrm{Ca}$, K, Ti and $\mathrm{Sr}$ in a Hudson volcano-related tephra layer from Laguna Cascada in South Chile.

Concerning the thick sandy to gravely event layers, similar coarse fining upward sedimentary deposits with an erosive base are often interpreted as resulting from floods deposited by hyperpycnal flows (e.g., Chapron et al., 2006). According to Mulder et al. (1998), the critical suspended-sediment concentration needed to produce a hyperpycnal plume in a lake is quite low and may result by river discharge into the lake. Among the event units observed in LJe14B, those layers with an erosive base (i.e. E3, E4 and E7) most probably record large floodtriggered turbidites. Only the upper sequence deposited during the falling limb of the flood is preserved, their basal coarsening upward sequence corresponding to the waxing flow being erased due to strong erosion (e.g., Guyard et al., 2007). In LJe14B, the event units are irregularly distributed over core depth, most of them being observed between 34 and $67 \mathrm{~cm}$ depth (Fig. 6). In particular, the event layers characterized by erosive bases may be triggered by different climate-related mechanisms (e.g., stormy winter conditions - Jenny et al., 2002 and/or exceptional snowmelt events, heavy rains, catastrophic drainage - Guyard et al., 2007) or tectonic-related mechanisms (e.g., slumps, earthquakes - Siegenthaler and Sturm 1991, 
563 Waldmann et al., 2011, Moernaut et al., 2018). The climate-driven mechanism is the most

564 probable as Lake Jeinimeni is located at the south eastern side of the influence area of the 565 Liquiñe-Ofqui Fault Zone (Thomson 2002).

$566 \quad$ 5.3. Meteorological calibration

567 The local instrumental data from Chile Chico station display a significant high correlation with CRU_TS precipitation $\left(\mathrm{R}^{2}\right.$ INIA-Pwinter $=0.93, \mathrm{p}<0.0001 ; \mathrm{R}^{2}$ INIA-Pannual $\left.=0.89, \mathrm{p}<0.0001\right)$ and temperature data $\left(\mathrm{R}^{2}\right.$ INIA-Twinter $=0.83, \mathrm{p}<0.0001 ; \mathrm{R}^{2}$ INIA-Tannual $\left.=0.79, \mathrm{p}<0.0001\right)$. The correlation analysis between meteorological parameters (i.e., annual and seasonal averaged temperature and precipitation) and sedimentological, geochemical proxies is shown in Table 4. In this, the varve thickness was retained as the main sedimentological proxy whereas the scores of the two first principal components PC1 and PC2 were chosen as geochemical proxies for grain-size (i.e., related to lake hydrodynamical conditions) and chemical weathering, respectively.

Among the selected proxies, the varve thickness was only sensitive to precipitation. The relationship between precipitation and varve was characterized by a Pearson correlation coefficient of -0.53 for annual precipitation and -0.71 in austral spring (i.e., September to November) (Table 4). As already presented in the first section of the discussion, such significant correlation supports the annually-resolved character of the sedimentation in LJe14B. The formation of clastic varves is mainly explained by seasonal runoff that carry suspended sediment into a stratified lake water body (Sturm, 1979). The thickness of the clastic varves,

583 like the ones observed in core LJe14B, is strongly controlled by the amount of snowmelt-related runoff (e.g., Cockburn and Lamoureux 2008). Such seasonally-contrasted sedimentation is reported worldwide in proglacial lakes (e.g., Leemann and Niessen 1994, Guyard et al., 2007). The coarse layer results of sediment settling during high hydrodynamic conditions whereas the 587 fine silt and clay layers result of particle settling in the water column during calm conditions. 
For Lake Jeinimeni record, the correlation with meteorological parameters (SM Fig.7, Table

4) showed that the varve thickness in core LJe14B was controlled by the precipitation abundance and its related surface runoff. However, the observed correlation is negative meaning that thicker (thinner) varves characterize dry (wet) periods. This observation suggests some contribution of an aeolian transport in the LJe14B sedimentation. The steep and narrow topography of the Lake Jeinimeni valley favours windy conditions throughout the year. However, the wind control on sediment transport is probably more pronounced-during the cold and locally dry austral summer corresponding to low runoff periods. A wind-control on varve thickness was proposed by Martin-Puertas et al. (2012) in the Meerfelder Maar record (Germany). In East Patagonia, the fastest winds that characterize the dry summer in the area may increase the erosive wave activity along the Lake Jeinimeni margins, providing detrital material to the lake. The fresh sedimentary deposits accumulated on the western margin of the Lake Jeinimeni during spring snowmelt could be especially sensitive to erosion and further transport by the lake hydrodynamic to the coring site.

Concerning the geochemical proxies, only PC1 presents a correlation with varve thickness, with thicker varves corresponding to higher PC1 scores $\left(\mathrm{R}^{2}{ }_{\mathrm{PC} 1 \text {-varve }}=0.54\right.$, Table 4, SM Fig. 5). This correlation evidences an important contribution of sediment particle transport, and further settling, during calm hydrodynamic conditions expressed by positive PC1 score. Those conditions favour the transport of the finest clayey silt particles. This hypothesis would be confirmed by a counting of the individual thickness of the coarsest and the finest laminae that compose the clastic varves of Lake Jeinimeni sedimentary record. However, as said earlier in the laminae description, the core LJe14B does not allow to do such counting. Indeed, there is no clear distinction between the coarse grained and overlying fine-grained laminae but rather a gradual boundary. 
In addition to varve thickness, the geochemical proxies were correlated to the first two 613 principal components. PC1 score displays a negative correlation with austral winter temperature $614\left(\mathrm{R}_{\text {JJA-PC1 }}^{2}=-0.54\right.$, Table 4, SM Fig. 5). Lower austral winter temperatures favour snow 615 accumulation and limits physical erosion. Only fine particulates (i.e., positive PC1) are 616 transported to the lake, mostly by winter deflation. Again, the aeolian transport seems to 617 contribute in a significant fraction of the particle settling in Lake Jeinimeni. The deployment of 618 seasonal sediment traps within the water column would confirm this hypothesis.

619 On the contrary, PC2 score is positively correlated to temperature, but only with austral 620 spring temperature $\left(\mathrm{R}^{2}\right.$ SON-PC2 $=0.58$, Table 4$)$. For Lake Jeinimeni area, the austral spring 621 warmer temperature is responsible for pronounced snow melting. The snowmelt delivers a high 622 sedimentary load driven by La Gloria stream (reported on Fig. 1C) recorded by the high spring 623 flow of the Jeinimeni River measured in Chile Chico station (Fig. 1B). The settling of such high 624 sedimentary load explains the pluri-millimetre sandy-layers observed at the bottom part of the 625 laminae couplet in LJe14B. In addition, the relationship between PC2 and SON temperature is 626 marked by a lag of a few years (SM Fig. 5). An increase in the Sr and Ca content of the lake 627 sediments (i.e., marked by a PC2 increase) occurs a few years later than a period of warmer 628 SON temperatures. This observation suggests more influence of physical weathering than 629 chemical one. Austral spring snowmelt upstream induces a downstream transport of less630 chemically-weathered material to the coring site.

631 Another geochemical ratio, i.e. $\mathrm{Si} / \mathrm{Al}$, is also highly correlated with precipitation $\left(\mathrm{R}^{2}{ }_{\text {annual P- }}\right.$ $632 \mathrm{Si} / \mathrm{Al}=0.72)$, the highest correlation being observed in fall $\left(\mathrm{R}^{2} \mathrm{MAM}-\mathrm{Si} / \mathrm{Al}=0.75\right)$. In the literature $633 \mathrm{Si} / \mathrm{Al}$ has been used as a proxy for grain-size (Davies et al., 2015; Kylander et al., 2011). In 634 core $\mathrm{LJe} 14 \mathrm{~B}$, the correlation of $\mathrm{Si} / \mathrm{Al}$ with austral winter temperature $\left(\mathrm{R}^{2}{ }_{J J A} \mathrm{Si} / \mathrm{Al}=0.50\right)$ rather 635 underlines a major runoff control. Indeed, the precipitation enhances physical weathering but 
also increase lake level. The overbank flooding reduces the energy hydrodynamics and favours

637 the settling of fine particles.

\subsection{Environmental variability over the last millennium}

Various sedimentological, glacial and biological archives have been investigated in continental and also in marine settings from Southern America to reconstruct the climate variability over the last millennia. An overview of the regional information deduced from these different archives retrieved at different longitude is given for a $20^{\circ}$ latitudinal transect from $33^{\circ}$ to $53^{\circ} \mathrm{S}$ in South America (Table 5). Some studies depict a general overview of the changes over the Holocene whereas others present detailed reconstructions allowing to evidence short climate event like MCA or LIA-type events. In addition, historical archives may also provide information on pronounced environmental changes related to rapid climate events like the LIA. The temporal resolution of each archive is controlled by its accumulation rate or growth rate combined with the sampling step resolution.

Among the numerous archives, varve thickness is commonly used as a high-resolution proxy of climate change (e.g., Zolitschka 1996, Kemp et al., 2001, Nederbragt and Thurow 2001, Haberzettl et al., 2005). For Lake Jeinimeni setting, the meterological calibration evidences that varve thickness of core LJe14B mainly reflects precipitation intensity. Varve counting in LJe14B allows a reconstruction of precipitation over, at least, $759 \pm 62$ years, i.e., from $\sim \mathrm{AD}$ 1250 to 2008. Note this time-window may be longer due to possible erosive influence of the events E3, 4 and 7 (Fig. 4C). The uncertainty on the age model precludes any time-series analysis. The sedimentary record of Lake Jeinimeni displays a pronounced multidecadal variability in varve thickness, by a factor of 1 to 8 , over core depth (Fig. 6). This observation that claims for strong variability in local precipitation is consistent with Late Holocene climate variability observed in North Patagonia (e.g., Villalba et al., 1990; Markgraf et al., 2013, Sepulveda et al., 2009; Masiokas et al., 2009). The reconstructed annual precipitation curve in 
LJe14B (Fig. 7) evidences a succession of wet (ca. AD 1259-1350, AD 1400-1450, AD 14801490, AD 1580-1610, AD 1650-1690, AD 1750-1800, AD 1820-1850, AD 1860-1920 and AD 1960-1990) and dry (ca. AD 1380-1400, 1700-1750 AD) intervals of variable, decadal to multidecadal, duration. Those climate fluctuations are roughly consistent to the Glacial Frias $\left(41^{\circ} 09^{\prime} \mathrm{S}, 71^{\circ} 48^{\prime} \mathrm{W}\right.$ - Fig. 7) fluctuations. Its dendrochonological-derived chronology is marked by 8 re-advances over the last 4 centuries at ca. AD 1638, 1717-1727, 1742-1752, 1835-1843, 1875-1884, 1912-1916, 1942-1943, and 1977-1978 (reported in Fig. 7), each of those been characterized by a cold and rainy interval recorded by a wider tree ring (Villalba et al., 1990). In LJe14B, the most marked drier interval is characterized by a sharp drop of precipitation ca. AD 1700 and a more gradual return to wetter conditions at ca. AD 1750. This dry interval precedes a wetter and colder phase reported from various North Patagonian archives such as tree rings (Villalba et al., 1990; Villalba 1994; Luckman and Villalba 2001; Villalba et al., 2003), extensive glacier advances (Masiokas et al., 2009, 2010), marine (e.g., core GeoB33131, Fig. 7 - Lamy et al., 2001), fjord (Jacaf, Fig. 7 - Sepulveda et al., 2009) and lacustrine (Lago Plomo, Fig. 7 - Elbert et al., 2012) sediments between ca. AD 1780 and 1850) and attributed to the LIA-like interval. North Patagonian glacial fluctuations over the last 1000 years have been studied by Rabassa et al. (1979, 1984), Villalba et al. (1990) and Masiokas et al. (2010). Villalba et al. (1990) emphasized the major glacial advances of the Frias Glacier (Fig. 7) between AD $1800-1850$ as the LIA event. Likely tree-ring dating indicated that the most extensive expansion of the Glacier Río Manso, $\left(41^{\circ} 12^{\prime} \mathrm{S}, 71^{\circ} 51^{\prime} \mathrm{W}\right)$ over the past several centuries took place between the late $1700 \mathrm{~s}$ and the $1830-40 \mathrm{~s}$ as the glacier thickened and advanced into adjacent forests (Masiokas et al. 2009). Further south the LIA-like event has been identified by the

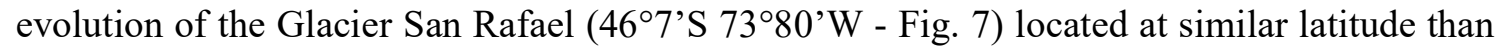
Lake Jeinimeni but on the western side of the North Patagonian Icefield. Based on documentary archives, Araneda et al. (2007) reconstructed the minimal and maximal extension of the Glacier 
687 San Rafael within the adjacent laguna (see location on Fig. 1). They identified the interval 688 comprised between AD 1766-1865 and AD 1871-1904 (Fig. 6) as an interval corresponding to 689 the LIA-type event in North Patagonia. The coldest interval ca. AD 1857-1871 is consistent 690 with literature compilation from Northern Patagonian Icefield (Masiokas et al., 2009). Indeed, 691 the dating of moraines and trimlines associated with 12 North Patagonian glaciers outlets 692 indicated major glacial advances between AD 1820-1850 (Masiokas et al., 2009), whereas the 693 LIA is identified $\leq 100$ to $300 \mathrm{yr}$ earlier in South Patagonia (Koch and Killian 2005), e.g., 694 between AD 1550-1800 (Moy et al., 2008). Therefore, the transition observed in LJe14B around 695 AD 1750 is consistent with the oldest limit of the LIA-type event in North Patagonia, i.e. a 696 youngest limit by comparison to the LIA interval for the Northern Hemisphere (i.e., AD 15701900 - Matthews and Briffa 2005).

698 The regional significance of the climate variability of Lake Jeinimini record has been further 699 assessed by the comparison with two varve sequences documented in North Chilean and 700 Argentinean Patagonia (Fig. 7). In 2012, Elbert et al. (2012) reported an annually-laminated 701 sedimentary record for $1530-2002 \mathrm{AD}$ from a proglacial lake (Lago Plomo $46^{\circ} 59^{\prime} \mathrm{S}, 72^{\circ} 52^{\prime} \mathrm{W}$, 702 203 masl - Fig. 7) located east of the Northern Patagonian Ice Field, at 75 km WSW of Lake Jeinimeni. Since no local meteorological station was available for the calibration, the mass accumulation rate (MAR) derived from the varves thickness were calibrated against austral winter (JJA) precipitation climate reconstruction data retrieved $47.0^{\circ} \mathrm{S} 72.5^{\circ} \mathrm{W}$ for the period AD 1930-2002). By reference to the calibration period, the reconstructed winter precipitation 707 curve (Fig. 7) evidenced 3 wetter intervals around AD 1600, AD 1630-1690 and AD 1780708 1850 , and a drier period AD 1690-1780 with a minimum at AD 1770. Those intervals are roughly consistent with the wet and dry intervals identified in LJe14B (i.e., AD 1580-1610, AD 1650-1690, AD 1750-1800 and AD 1700-1750). The time lag of 10 to 30 years remains within

711 the calculated uncertainty of the varve counting in LJe14B (i.e., \pm 62 years). 
Likely Ariztegui et al. (2007) investigated a 180 year-varve thickness record in a proglacial 713 lake (Laguna Frias, Argentina, 40 S - Fig. 7). The authors emphasized that varve thickness 714 variations mimict the Frias glacier $\left(41^{\circ} 09^{\prime} \mathrm{S}, 71^{\circ} 48^{\prime} \mathrm{W}\right.$ - Fig. 7) fluctuations (Villalba et al. 715 1990), with thicker varves during glacial re-advances. Most of those glacier readvances have 716 been recorded in Lago Frias by the sedimentation of a thicker detrital clayey to silty laminations, 717 linked to the abrasion of the bedrock by the glacier.

718 Moreover, some regional-scale coherency with the LJe14B record is even observed with 719 lacustrine sequences from Central Chile. A 600 year-varve sequence retrieved from Lago 720 Puyehue (40 S, Fig. 7) was divided by 8 periods (Boës and Fagel 2008; Fagel et al., 2008). The 721 thin varve thickness from ca. AD 1400-1510 in Lake Puyehue is consistent with the dry period 722 observed in LJe14B between AD 1400-1450, had been interpreted as low lake level during the late MCA interval. The interval ca. AD 1510-1630, characterized by thicker varves, indicated more humid conditions in central Chile in comparison with the present-day regional climate conditions. It covers two successive wet phases evidenced in LJe14B (i.e., AD 1480-1490 and 726 1580-1610) and was also recorded in Lake Plomo (ca. AD 1600). Between ca. AD 1630 to 1730 and AD 1780-1820, two significant increases in varve thickness attested for another wetter phases, consistent with the wet LJe14B intervals at AD 1650-1690 and AD 1750-1800 but also with those recorded in the Lake Plomo record at AD 1630-1690 and AD 1780-1850. There are interrupted by a drop in the precipitations from ca. AD 1730 to 1780 that corresponds to dry intervals in LJe14B ( $\sim$ AD 1700-1750) and in Lake Plomo ( AD 1690-1780). The nineteen century mainly recorded wetter conditions in Lake Puyehue sequence, with a wet interval over AD 1820-1920 that covers 2 wet intervals evidenced in LJe14B at ca. AD 1820-1850 and AD 1860-1920. The next wet interval evidenced in Lake Puyehue between AD1920-1950 is not observed in LJe14B. Note the uppermost interval in the Lake Puyehue record was perturbed by an earthquake deposit at AD 1960. 
For a northern site, a multiproxy study of the sedimentary sequence of Laguna Aculeo $\left(33^{\circ} \mathrm{S}\right.$,

738 see location on Fig. 7) emphasized several clastic layers over the last 2 millennia (Jenny et al., 739 2002). Those deposits that occurred around ca. AD 200-400, 500-700, AD 1300-1700, and AD

$740 \quad 1850-1998$ were interpreted as floods and correlated with winter rains from the SWW (Jenny

741 et al., 2002). The termination of the AD 1300-1700 flood event is consistent with the inception

742 of the dry interval recorded between ca. AD 1700-1750 in LJe14B. The inception of the next

743 flood event coincides with the end of the maximum extent of LIA as reported in North Patagonia

744 (e.g., Araneda et al., 2007; Masiokas et al., 2009).

745 To summarize the regional overview, the precipitation record of Lake Jeinimeni is consistent 746 with published paleoclimate reconstructions derived from different climate archives studied in 747 Southern America.

\section{Conclusion}

The sedimentological and geochemical study carried out on Lake Jeinimeni sediments emphasizes environmental and climate variabilities in NE Chilean Patagonia, in agreement with climate reconstructions deduced from both marine and continental North Patagonian archives. The varved core LJe14B records recurrent hydrodynamical changes in the lake watershed, with seasonal clastic flood supplies related to austral spring temperature and snowmelt discharge. In addition, the presence of a few thick layers between 1700 and 1850AD underlines exceptional erosive conditions with the watershed responsible for major floods. The inverse relationship between varve thickness and precipitation indicates a contribution of aeolian transport within the LJe14b record during cold and dry austral summer. This could be especially true in lakes located in the forest-steppe ecotone like Lake Jeinimeni which is located in the lee side of the Patagonian Andes where an increase in the SWW could be reflected as an increase in aeolian transport of particles producing a thicker varve. 
The climate interpretation is limited by the potential disturbance due to the deposition of

those massive events. A distal coring site would bring a more continuous varved-record allowing to count individual laminae but also to perform spectral analyses on time-series and therefore further investigate the climate forcing. Precipitation-sensitive proxies (i.e., varvethickness, $\mathrm{Si} / \mathrm{Al}$ ) display a high variability in the LJe14B sequence over at least $759 \pm 62$ years. The highest variability is reported for the oldest part of the LIA-type event (ca. 1750AD), in agreement with tree-ring records and glacial advances reported in North Patagonia, and quantitative precipitation reconstructions derived from lacustrine laminated sequences from both North Patagonia and Central Chile.

\section{Acknowledgements}

We thank Jorge Félez and Alex Henríquez from University of Concepcion for their help in elaboration of the geological and bathymetric maps; Isabel Israde Alcantara from the University of Morelia (Mexico) for diatom identification; Frederic Boulvain for thin section observation.

This research was funded by WBI-Chile bilateral collaboration project and by Chilean Fondecyt funding 1201277. In addition, Roberto Urrutia thanks the project ANID/FONDAP/15130015 and Pablo Pedreros the Fondecyt Postdoctoral funding 3180356.

\section{References}

Abbott M.B. and Stafford T.W. (1996). Radiocarbon Geochemistry of Modern and Ancient Arctic Lake Systems, Baffin Island, Canada. Quat. Res., 45, 300-311.

Albéric P., Jézéquel D., Bergonzini L., Chapron E., Viollier E., Massault M. and Michard G. (2016). Carbon Cycling and Organic Radiocarbon Reservoir Effect in a Meromictic Crater Lake (Lac Pavin, Puy-de-Dôme, France). Radiocarbon, 55, 1029-1042. 
Alvarez D., Fagel N., Araneda A., Jana-Pinninghoff P., Keppens E., Urrutia R. (2015). Late Holocene climate variability on the eastern flank of the Patagonian Andes (Chile): $\mathrm{A} \delta^{18} \mathrm{O}$ record from mollusks in Lago Cisnes $\left(47^{\circ} \mathrm{S}\right) .25(8)$. The Holocene 25 (8), 1220-1230.

Appleby P.G. and Oldfield F. (1978). The Calculation of Lead-210 Dates Assuming a Constant Rate of Supply of Unsupported 210Pb to the Sediment. CATENA 5, 1-8.

Aritzigui D., Bösch P., Davaud E. (2007). Dominant ENSO frequencies during the Little Ice Age in Northern Patagonia: The varved record of proglacial Lago Frías, Argentina. Quaternary International 161, 46-55.

Araneda A., Torrejón F., Aguayo M., Torres L., Crucres F., Cisternas M. and Urrutia R. (2007). Historical records of San Rafael glacier adavances (North Patagonia icefield): another clue to 'Little Ice Age' in southern Chile? The Holocene 17(7), 989-1000.

Avşar U., Hubert-Ferrari A., De Batist M., Fagel N. (2014). A 3400 years lacustrine paleoseismic record from the North Anatolian Fault, Turkey: Implications for bimodal recurrence behaviour. Geophysical Research Letters 41, 3773-84, doi:10.1002/2013GL058221.

Bertrand S., Boës X., Castiaux J., Charlet F., Urrutia R., Espinoza C., Lepoint G., Charlier, B., Fagel, N. (2005). Temporal evolution of sediment supply in Lago Puyehue (Southern Chile) during the last $600 \mathrm{yr}$ and its climatic significance. Quaternary Research 64, 163-175.

Bertrand S., Araneda A., Vargas P., Jana P., Fagel N., Urrutia R. (2012). Using the N/C ratio to correct bulk radiocarbon ages from lake sediments: Insights from Chilean Patagonia. Quaternary Geochronology 12, 23-29. doi: 10.1016/j.quageo.2012.06.003.

Bertrand S., Hughen K., Sepúlveda J., Pantoja S. (2014). Late Holocene covariability of the southern westerlies and sea surface temperature in northern Chilean Patagonia Quaternary Science Reviews 105,195-208. 
811 Blaauw M. (2010a). Methods and code for 'classical' age-modelling of radiocarbon sequences.

812 Quaternary Geochronology 5(5), 512-518. https://doi.org/10.1016/j.quageo.2010.01.002.

813 Blaauw M. (2010b). R-Code for 'classical' age-modelling (CLAM V1.0) of radiocarbon

814 sequences. PANGAEA, https://doi.org/10.1594/PANGAEA.873023.

815 Boës X. and Fagel N. (2008). Relationships between southern Chilean varved lake sediments,

816 precipitation and ENSO for the last 600 years. Journal of Paleolimnology 39, 237-252. Doi:

$817 \quad 10.1007 / \mathrm{s} 10933-007-9119-9$.

818 Boës X, Rydberg J, Martinez-Cortizas A, Bindler R, Renberg I (2011) Evaluation of

819 conservative lithogenic elements $(\mathrm{Ti}, \mathrm{Zr}, \mathrm{Al}$, and $\mathrm{Rb}$ ) to study anthropogenic element 820 enrichments in lake sediments. Journal of Paleolimnology 46, 75-87.

821 Boski T., Pessoa J., Pedro P., Thorez J., Dias J.M.A., Hall I.R. (1998). Factors governing 822 abundance of hydrolysable amino acids in the sediments from the N.W. European 823 Continental Margin $\left(47-50^{\circ} \mathrm{N}\right)$. Progress in Oceanography 42, 145-164.

824 Bradley R.S., Briffa K.R., Cole J., Hughes M.K., Osborn T.J. (2003). The climate of the 825 last millennium. In: Alverson K.D., Bradley R.S., Pederson T.F. (Eds.), Paleoclimate, Global 826 Change and the Future. Springer, New York, pp. 105-141.

827 Chapron E., Ariztegui D., Mulsow S., Villarosa G., Pino M., Outes V., Juvigné E., Crivelli E., 828 (2006). Impact of the 1960 major subduction earthquake in Northern Patagonia. Quaternary 829 International 158, 58-71.

830 Cherniak D.J. (2002), Ba diffusion in feldspars. Geochimica et Cosmochimica Acta 66(9), $831 \quad 1641-1650$.

832 Cockburn J.M.H. and Lamoureux S.F. (2008). Inflow and lake controls on short-term mass 833 accumulation and sedimentary particle size in a High Arctic lake: implications for 834 interpreting varved lacustrine sedimentary records. Journal of Paleolimnology 40 (3), 923 835 942. http://dx.doi.org/10.1007/s10933-008-9207-5. 
Corporación Nacional Forestal CONAF (2017). Plan de uso público Reserva Nacional Lago Jeinimeni. República de Chile-Ministerio de Agricultura, p. 27-30.

Cook H.E., Johnson P.D., Matti J.C., Zemmels I. (1975). Methods of sample preparation and X-ray diffraction data analysis in: X-ray mineralogy laboratory. In: Kaneps AG (ed.) Initial Reports of the DSDP. Washington, DC: Printing Office. pp. 997-1007.

Croudarce I.W. and Rothwell R.G. (2015). Micro-XRF studies of sediment cores. Developments in paleoenvironmental Research 17, Springer Science, Dordrecht, 189-226. DOI 10.1007/978-94-017-9849-5-7.

Davies S.J., Lamb H. F., Roberts S.J. (2015). Micro-XRF Core scanning in paleolimnology: recent developments. In I.W. Croudarce and R.G. Rothwell (eds.), Micro-XRF studies of sediment cores. Developments in paleoenvironmental Research 17, Springer Science, Dordrecht, 189-226.

Davis J.C. (2002). Statistics and data analysis in Geology. J. Wiley \& sons, New York, 638 pp.

De la Cruz R., Suarez M. and Formato M. (2003) Geologia del area puerto guadal-puerto sanchez, region aisen del general carlos ibanez del campo, escala 1. 100000. $n^{\circ}$ mapa: m113. Santiago: Servicio Nacional de Geologia y Mineria-Chile.

Dirección General de Aeronáutica Civil (DGAC) (2020). Anuario Meteorológico 2019. Editorial Dirección Meteorológica de Chile, Santiago de Chile., 85-86. https://climatologia.meteochile.gob.cl/application/index/anuarios.

Elbert J., Grosjean M., von Gunten L., Urrutia R., Fischer D., Wartenburger R, Ariztegui D., Fujak M. and Hamann Y. (2012). Quantitative high-resolution winter (JJA) precipitation reconstruction from varved sediments of Lago Plomo $47^{\circ} \mathrm{S}$, Patagonian Andes, AD 15302002. The Holocene 22(4) 465-474. DOI: 10.1177/0959683611425547.

Encinas A., Folguera A., Riffo R., Molina P., Fernandez Paz L., Litvak V.D., Colwyn D.A., Valencia V.A., Carrasco, M. (2018). Cenozoic basin evolution of the Central Patagonian 
Andes: Evidence from geochronology, stratigraphy, and geochemistry, Geoscience Frontiers https://doi.org/10.1016/j.gsf.2018.07.004.

Escobar, F., Vidal, F., Garin, C., Naruse, R. (1992). Water balance in the Patagonian Icefield. In: Naruse, R., Aniya, M. (Eds.), Glaciological Researches in Patagonia, 1990. Japanese Society of Snow and Ice, 109-119.

Fagel N., Boës X., Loutre M. F. (2008). Climate oscillations evidenced by spectral analysis of Southern Chilean lacustrine sediments: the assessment of ENSO over the last 600 years. Journal of Paleolimnology 39, 253-266.

Fagel N., Alvarez D., Namur O., Devidal J.L., Nuttin L., Schmidt, S., Jana P., Torrejon F., Bertrand S., Araneda A. and R. Urrutia (2017). Lacustrine record of last millenia eruptions in Northern Chilean Patagonia (45-47º S). The Holocene. Doi 10.1177/0959683616687380.

Folk R.L. and Ward W.C. (1957). A study in the significance of grain-size parameters. Journal of Sedimentary Petrology 27, 3-26.

Fuenzalida R. (1976). The Hudson volcano. Proceedings of the lA VCEI Symposium on Andean and Antarctic Volcanology Problems, 78-87. Santiago, Chile, 1974.

Garreaud R.D. (2007). Precipitation and circulation covariability in the extratropics. Journal of Climate 20, 4789-4797, doi: 10.1175/JCLI4257.1.

Garreaud R.D., Vuille M., Compagnucci R., Marengo J. (2009). Present-day South America climate. Paleogeography, Paleoclimatology, Palaeoecology 281, 180-195.

Garreaud R.D., Lopez P., Minvielle M., Rojas M. (2013). Large-Scale Control on the Patagonian Climate. Journal of Climate 26, 215-230. doi: 10.1175/JCLI-D-12-00001.1

Gilli A., Ariztegui D., Anselmetti F.S., McKenzie J., Markgraf V., Hajdas I., McCulloch R.D. (2005). Mid-Holocene strengthening of the southern westerlies in South Americasedimentological evidences from Lago Cardiel, Argentina $\left(49^{\circ} \mathrm{S}\right)$. Global and Planetary Change 49, 75-93. 
886 Glasser N.F., Jansson K.N., Harrison S., Kleman J. (2008). The glacial geomorphology and 887 Pleistocene history of South America between $38^{\circ}$ and $56^{\circ} \mathrm{S}$, Quaternary Science Reviews $27,365-390$.

Glasser N.F., Harrison S., Schnabel C., Fabel D., Jansson K.N. (2012). Younger Dryas and early Holocene age glacier advances in Patagonia, Quaternary Science Reviews 58, 7-17.

Gyuard H., Chapron E., St-Onge G., Anselmetti F. S., Arnaud F., Magand O., Francus P., 892 Mélières M.A. (2007). High-altitude varve records of abrupt environmental changes and 893 mining activity over the last 4000 years in the Western French Alps (Lake Bramant, Grandes Rousses Massif). Quaternary Science Reviews 26, 2644-2660.

Haberzettl T., Fey M., Lücke A., Maidana N., Mayr C., Ohlendorf C., Schäbitz F., Schleser last two millennia as reflected in sediments of Laguna Potrok Aike, southern Patagonia Patagonia (Santa Cruz, Argentina). Journal of Paleolimnology 33, 283-302.

Harris I.C., Jones P.D. (2020). CRU TS4.03: Climatic Research Unit (CRU) Time-Series (TS) version 4.03 of high-resolution gridded data of month-by-month variation in climate (Jan. 1901- Dec. 2018). Centre for Environmental Data Analysis, 22 January 2020. doi:10.5285/10d3e3640f004c578403419aac167d82. http://dx.doi.org/10.5285/10d3e3640f 004c578403419aac167d82

Hepp C., Reyes C., Muñoz R. (2018). Análisis de datos históricos de cinco estaciones meteorológicas de la región de Aysén. Boletín Técnico N³65. Instituto de Investigaciones Agropecuarias, Centro de Investigación INIA Tamel Aike, Coyhaique, Aysén-Patagonia, Chile. 200 pp (In Spanish).

Hedges J.I. and Stern J.H. (1984). Carbon and nitrogen determinations of carbonate-containing solids. Limnolology and Oceanography 29(3), 1984, 657-663. 
Henríquez M. and Alvear N. (1987). Guía de Manejo Reserva Nacional Lago Jeinimeni. República de Chile-Ministerio de Agricultura, Corporación Nacional Forestal (CONAF), p. 42. (In Spanish).

Hein A. S., Hulton N. R. J., Dunai T. J., Schnabel C., Kaplan M. R., Naylor M., Xu S. (2009). Middle Pleistocene glaciation in Patagonia dated by cosmogenic-nuclide measurements on outwash gravels. Earth and Planetary Science Letters 286 (1-2), 184-197.

Hein A.S., Hulton N.R.J., Dunai T.J., Sugden D.E., Kaplan M.R., Xu S. (2010). The chronology of the Last Glacial Maximum and deglacial events in central Argentine Patagonia, Quaternary Science Reviews 29, 1212-1227.

Heiri A., Lotter F. and Lemcke G. (2001) Loss on ignition as a method for estimating organic and carbonate content in sediments: Reproducibility and comparability of results. Journal of Paleolimnology 25(1), 101-110.

Hepp, C., Reyes, C. y Muñoz, R. 2018. Análisis de datos históricos de cinco estaciones meteorológicas de la región de Aysén. Boletín Técnico N365. Instituto de Investigaciones Agropecuarias, Centro de Investigación INIA Tamel Aike, Coyhaique, Aysén-Patagonia, Chile. 200 pp.

Heusser L., Heusser, C., Pisias, N. (2006). Vegetation and climate dynamics of southern Chile during the past 50,000 years: results of ODP Site 1233 pollen analysis. Quaternary Science Reviews 25, 474-485.

Hogg A. G., Hua Q., Blackwell P.G., Niu M., Buck C. E., Guilderson T. P., Heaton T.J., Palmer J. G., Reimer P. J., Reimer R. W., Turney C. S. M., Zimmerman S. R. H. (2013). SHCal13 Southern Hemisphere Calibration, 0-50,000 Years cal BP. Radiocarbon 55(4), 1889-1903. Jenny B., Valero-Garces B. L., Urrutia R., Kelts K., Veit H., Appleby P. G., Geyh M. (2002). Moisture changes and fluctuations of the Westerlies in Mediterranean Central Chile during 
the last 2000 years: The Laguna Aculeo record $\left(33^{\prime} 50^{\circ} \mathrm{S}\right)$. Quaternary International 87, 318.

Kemp A.E.S, Dean J., Pearce R.B., Pike J. (2001). Recognition and analysis of bedding and sediment fabric features. In: Last, Smol (eds) Tracking environmental change using lake sediments. Physical and geochemical Methods, vol 2, Kluwer Academic Publishers, Dordrecht, The Netherlands, 7-22.

Kylander M., Ampel L., Wohlfarth B., Veres. D. (2011). High-resolution X-ray fluorescence core scanning analysis of Les Echets (France) sedimentary sequence: new insights from chemical proxies; J. Quat. Sci. 26, 109-117.

Koch, J. and Kilian, R. (2005). "Little Ice Age” glacier fluctuations, Gran Campo Nevado, southernmost Chile. The Holocene 15, 20-28.

Lamy F., Hebbelm D., Rohl U., Wefer G. (2001). Holocene rainfall variability in southern Chile: A marine record of latitudinal shifts of the southern westerlies. Earth and Planetary Science Letters 185, 369-382.

Lamy, F., Kilian, R., Arz, H.W., Francois, J.P., Kaiser, J., Prange, M., Steinke, T. (2010). Holocene changes in the position and intensity of the southern westerly wind belt. Nature Geoscience 3, 695-699.

Leemann A. and Niessen F. (1994). Varve formation and the climatic record in an Alpine proglacial lake: calibrating annually laminated sediments against hydrological and meteorological data. The Holocene 4, 1-8.

Luckman B.H. and Villalba R. (2001). Assessing the synchroneity of glacier fluctuations in the western cordillera of the Americas during the last millennium. In: Markgraf V. (Ed.),

957 Luebert F. and Pliscoff P. (2006). Sinopsis bioclimática y vegetacional de Chile. Editorial $958 \quad$ Universitaria: Santiago. 
Mann M E., Zhang Z.H., Rutherford S., Bradley R.S., Hughes M.K., Shindell D., Ammann C., Faluvegi G., Ni F.B. (2009). Global signatures and dynamical origins of the Little Ice Age and Medieval climate anomaly. Science 326, 1256-1260.

Markgraf, V. (1993). Paleoenvironments and paleoclimates in Tierra del Fuego and southernmost Patagonia, South America. Palaeogeography, Palaeoclimatology, Palaeoecology 102 (1-2), 53-68.

Markgraf, V., Dodson, J.R., Kershaw, A.P., McGlone, M.S., Nicholls, N. (1992). Evolution of Late Pleistocene and Holocene climates in the circum-South Pacific land areas. Climate Dynamics 6, 193-211.

Markgraf, V., Bradbury, J.P., Schwalb, A., Burns, S.J., Stern, C., Ariztegui, D., Gilli, A., Anselmetti, F.S., Stine, S., Maidana, N. (2003). Holocene palaeoclimates of southern Patagonia: limnological and environmental history of Lago Cardiel, Argentina $\left(49^{\circ} \mathrm{S}\right)$. Holocene 13 (4), 581- 591.

Markgraf V., Iglesias V., Whitlock C. (2013). Late and postglacial vegetation and fire history from Cordón Serrucho Norte, northern Patagonia. Palaeogeography, Palaeoclimatology, Palaeoecology 371, 109-118.

Martin-Puertas C, Brauer A, Dulski P. (2012). Testing climate-proxy stationarity throughout the Holocene: an example from the varved sediments of Lake Meerfelder Maar (Germany). Quaternary Science Reviews 58, 56-65.

Masiokas M.H., Luckman B.H., Villalba R., Delgado S., Skvarca P., Ripalta A. (2009). Little Ice Age fluctuations of small glaciers in the Monte Fitz Roy and Lago del Desierto areas, south Patagonian Andes, Argentina. Palaeogeography, Palaeoclimatology, Palaeoecology $281,351-362$. 
982 Masiokas M.H., Luckman B.H., Villalba R., Ripalta A., Rabassa J. (2010). Little Ice Age 983 fluctuations of Glaciar Río Manso in the north Patagonian Andes of Argentina. Quaternary $984 \quad$ Research 73, 96-106.

985 Masson-Delmotte V. et al. in Climate Change (2013). The Physical Science Basis 986 Contribution of Working Group I to the Fifth Assessment Report of the 987 Intergovernmental Panel on Climate Change (eds. Stocker T. F. et al.), Cambridge Univ. $988 \quad$ Press, 383-464.

989 Matthews J.A and Briffa K.R. (2005). The 'Little Ice Age': Re-evaluation of an evolving $990 \quad$ concept. Geogr. Ann 87, 17-36.

991 Mayr C., Lücke A., Wagner S., Wissel H., Ohlendorf C., Haberzettl T., Oehlerich M., 992 Schäbitz F., Wille M., Zhu J. (2013). Intensified Southern Hemisphere Westerlies 993 regulated atmospheric CO2 during the last deglaciation. Geology 41, 831-834.

994 Mayr C., Fey M., Haberzettl T. et al. (2005). Palaeoenvironmental changes in southern 995 Patagonia during the last millennium recorded in lake sediments from Laguna Azul 996 (Argentina). Palaeogeography, Palaeoclimatology, Palaeoecology 228, 203-227.

997 Mayr C, Wille M, Haberzettl T et al. (2007). Holocene variability 998 of the Southern Hemisphere westerlies in Argentinean Patagonia (52 $\left.{ }^{\circ} \mathrm{S}\right)$. Quaternary Science $999 \quad$ Reviews 26, 579-584.

1000 Meyers P. A. and Teranes J. L. (2001). Sediment organic matter. In W. M. Last \& J. P. Smol 1001 (Eds). Tracking environmental change using lake sediments, vol. Volume 2, Physical and 1002 geochemical methods, p. 239-269. Kluwer Academic Publishers: Dordrecht, Netherlands. 1003 Moernauts J., Van Daele M., Fontijn K., Kempf P., Pino M., Valdebenito G., Urrutia R., 1004 Strasser M., De Batist M. (2018), Larger earthquakes recur more periodically: New insights 1005 in the megathrust earthquakes cycle in lacustrine turbidite records in south-central Chile. 1006 Earth Planetary Science Letters 481, 9-19. 
Montecinos A. and Aceituno P. (2003). Seasonality of the ENSO-Related Rainfall Variability in Central Chile and Associated Circulation Anomalies. American Meteorological Society $16,281-296$.

Moore D. and Reynolds R.C. Jr. (1997). X-Ray Diffraction and the Identification and Analysis of Clay Minerals. Oxford: Oxford University Press, 332 pp.

Moreno, P.I., Jacobson, G.L., Lowell, T.V., and Denton, G.H. (2001). Interhemispheric climate links revealed by a late-glacial cooling episode in southern Chile. Nature 409, 804-808, doi: $10.1038 / 35057252$.

Moreno P.I., Francois J.P., Villa-Martinez R.P., Moy C.M. (2009). Millennial-scale variability in Southern Hemisphere westerly wind activity over the last 5000 years in SW Patagonia: Quaternary Science Reviews 28, 25-38, doi: 10.1016/j.quascirev.2008.10.009.

Moy C.M., Dunbar R.B., Moreno P.I., Francois J.P., Villa-Martínez R., Mucciarone D.M., Guilderson T.P., Garreaud R.D. (2008). Evidence for hydrologic change related to the westerlies in SW Patagonia, Chile, during the last millennium. Quaternary Science Reviews 27, 1335-1349, doi: 10.1016/j.quascirev.2008.03.006.

Moy C.M., Moreno P.I., Dunbar R.B., Kaplan M.R., Francois J.P., Villalba R., Haberzettl T. (2009). Climate change in Southern South America during the last 2 millennia. In: Vimeux et al. (eds.). Past Climate variability in South America and surrounding regions. Developments in Paleoenvironmental Research 14, 353-387. doi 10.1007/978-90-481-26729_15.

Moy C.M., Dunbar, R.B., Guilderson T.P., Waldmann N., Mucciarone D.A., Recasens C., Ariztegui D., Austin Jr J.A. and Anselmetti F.S. (2011). A geochemical and sedimentary record of high southern latitude Holocene climate evolution from Lago Fagnano, Tierra del Fuego. Earth and Planetary Science Letters 302, 1-13 
Mulder T., Syvitski J.P.W., Skene K.I. (1998). Modelling of erosion and deposition by turbidity currents generated at river mouths. Journal of Sedimentary Research 68, 124-137.

Naranjo J.A. and Stern C.R. (1998). Holocene Explosive Activity of Hudson Volcano, Southern Andes, Bull. Volcanol. 59, 291-306.

Naranjo J.A., Moreno H., N. G. Banks (1993). La erupción del volcán Hudson en 1991 (46S), Región de Aisén, Chile, Servicio Nacional de Geología y Minería, Boletin 44 Santiago, 50 pp.

National Center for Atmospheric Research Staff (2017). The Climate data Guide CRU TS gridded precipitation and other meteorological variables since 1900. Retrieved from

https://climatedataguide.ucar.edu/climate-data/cru-ts-gridded-precipitation-and-othermeteorological-variables-1901.

Nederbragt A.J. and Thurow J.W. (2001). A 6000 years varve record of Holocene climate in Saanich Inlet, British Columbia, from digital sediment colour analysis of ODP Leg 169S cores. Marine Geology 174, 95-110.

Neukom R., Luterbacher J., Villalba R., Kuttel M., Frank D., Jones P.D., Grosjean M., Esper J., Lopez L., Wanner H. (2010). Multi-centennial summer and winter precipitation variability in southern South America. Geophysical Research Letters 37.

Neukom R., Steiger N., Gómez-Navarro J.J. et al. (2019). No evidence for globally coherent warm and cold periods over the preindustrial Common Era. Nature 571, 550-554. https://doi.org/10.1038/s41586-019-1401-2.

New M., Lister D., Hulme M., Makin I. (2002). A high-resolution data set of surface climate over global land areas. Climate Research 21, 1-25. doi:10.3354/cr021001.

Orihashi Y., J.A. Naranjo, A. Motoki, H. Sumino, D. Hirata, R. Anma, K. Nagao (2004). Quaternary volcanic activity of Hudson and Lautaro volcanoes, Chilean Patagonia: New 
constraints from K-Ar ages. Revista Geológica de Chile 31(2), 207-224. http://dx.doi.org/10.4067/S0716-02082004000200002.

Pankhurst R.J., Weaver S. D., Hervé F., Larrondo P. (1999). Mesozoic-Cenozoic evolution of the North Patagonian Batholith in Aysen, southern Chile. Journal of the Geological Society 156(4), 673-694.

Pfeiffer M., Mascayano C., Aburto F. (2010). Soils of Chilean Patagonia in glacial and periglacial environments. Eurasian Soil Sciences 43(13), 1430-1438.

Quade J. and Kaplan M.R. (2017). Lake-level stratigraphy and geochronology revisited at Lago (Lake) Cardiel, Argentina, and changes in the Southern Hemispheric Westerlies over the last 25 ka. Quaternary Science Reviews 177, 173-188.

Quiroz R., Popp P., Urrutia R., Bauer C., Araneda A., Treutler H.C., Barra R. (2005). PAH fluxes in the Laja Lake of south central Chile Andes over the last 50 years: Evidence from a dated sediment core. Science of total Environment 349, 150-160.

Rabassa J., Rubulis, S. Suarez J. (1979). Rate of formation and sedimentology of (1976-1978) push-moraines, Frias Glacier, Mount Tronador $\left(41^{\circ} 10 \mathrm{~S}, 71^{\circ} 53 \mathrm{~W}\right)$, Argentina. In: Schlüchter, Ch. (Ed.), Moraines and Varves. Rotterdam, Balkema, pp. 65-79.

Rabassa J., Brandani A., Boninsegna J.A., Cobos D.R. (1984). Cronología de la "Pequeña Edad del Hielo" en los glaciares Río Manso y Castaño Overo, Cerro Tronador, Provincia de Río Negro. Noveno Congreso Geológico Argentino, Actas 3, 624-639.

R Development Core Team (2016). R: A Language and Environment for Statistical Computing. R Foundation for Statistical Computing, Vienna, Austria. ISBN 3-900051-070, URL http://www.R-project.org/.

Revelle W. (2017). Psych: Procedures for Personality and Psychological Research. NorthWestern University, Evanston. R package version 1.7.12. URL http://personalityproject.org/r/psych. 
Richter T.O., Van der Gaast S., Koster B., Vaars A., Gieles R., De Stigter H., De Haas H., van Weering T.C.E. (2006). The Avaatech XRF core scanner: technical description and applications to NE Atlantic sediments. In: Rothwell, R.G. (Ed.), New Techniques in Sediment Core Analysis. Special Publication, vol. 267. Geological Society, London, 39-50.

Röhlisberger E., 1986. 1000 Jahre Glestschergerchichte der Erde. Verlag Sauerlander, Salzburg.

Rothwell R.G. and Rack F.R. (2006). New techniques in sediment core analysis: an introduction. In: Rothwell, R.G. (Ed.), New Techniques in Sediment Core Analysis. Special Publication, vol. 267. Geological Society, London, 1-29.

Rothwell R.G. and Croudarce I.W. (2015). Twenty Years of XRF Core Scanning Marine Sediments: What Do Geochemical Proxies Tell Us? In: Croudarce I.W. and Rothwell R.G. (eds.). Micro-XRF studies of sediment cores. Developments in paleoenvironmental Research 17, Springer Science, Dordrecht, 189-226. DOI 10.1007/978-94-017-9849-5-7.

Schimpf D., Kilian R., Kronz A., Simon K., Spotl C., Worner G., Deininger M., Mangini A. (2011). The significance of chemical, isotopic, and detrital components in three coeval stalagmites from the superhumid southernmost Andes (53S) as high-resolution palaeo-climate proxies. Quaternary Science Review 30, 443-459.

Sepulveda J., Pantoja S., Hughen K.A., Bertrand S., Figueroa D., León T., Drenzek, N.J., Lange, C. (2009). Late Holocene sea-surface temperature and precipitation variability in northern Patagonia, Chile (Jacaf Fjord, 44º S). Quaternary Research 72, 400-409.

Siegenthaler C. and Sturm M. (1991). Slump induced surges and sediment transport in Lake Uri, Switzerland. Int. Assoc. Theor. Applied Limnology Proceedings, 24(2), 955-958.

Sperazza M., Moore J., Hendrix M. (2004). High-resolution particle size analysis of naturally occurring very fine-grained sediment through laser diffractometry. Journal of Sedimentary Research 74 (5) 736-743. 
1105 Stern C.R. (2004). Active Andean Volcanism: Its Geologic and Tectonic Setting, Rev. Geol.

$1106 \quad$ Chile $31(2), 161-206$.

1107 Stern C.R., de Porras M.E., Maldonado A. (2015). Tephrochronology of the upper Río Cisnes 1108 valley $\left(44^{\circ} \mathrm{S}\right)$, southern Chile. Andean Geology 42 (2), 173-189.

1109 Stupar Y.V., Schäfer J., García M.G., Schmidt S., Piovano E., Blanc F., Huneau G., Le

1110 Coustumer P. (2014). Historical mercury trends recorded in sediments from the Laguna del

1111 Plata, Córdoba, Argentina. Chemie der Erde Geochimistry 74, 353-363.

1112 Sturm M. (1979). Origin and composition of clastic varves. In: Schlüchter, C. (Ed.),

1113 Moraines and Varves: Origin, Genesis, Classification. A.A. Balkema, Rotterdam,

1114 The Netherlands, pp. 281-285. http://www.worldcat.org/title/moraines-andvarves-origin1115 genesis-classification/oclc/5542145.

1116 Thomson S. N. (2002). Late Cenozoic geomorphic and tectonic evolution of the Patagonian 1117 Andes between latitudes $42^{\circ} \mathrm{S}$ and $46^{\circ} \mathrm{S}$ : An appraisal based on fission-track results from the 1118 transpressional intra-arc Liquiñe-Ofqui fault zone. Geological Society of America Bulletin $1119 \quad 114(9), 1159-1173$.

1120 Trenbeth K.E. (1991). Storm tracks in the Southern Hemisphere. Journal of the Atmospheric $1121 \quad$ Sciences, 48 (19), 2159-2178.

1122 Unkel I., Fernandez M., Bjorck S., Ljung K., Wohlfarth B. (2010). Records of environmental 1123 changes during the Holocene from Isla de los Estados $\left(54.4^{\circ} \mathrm{S}\right)$, southeastern Tierra del 1124 Fuego. Global Planetary Change 74, 99-113.

1125 Vandekerkhove E., Bertrand S., Reid B., Bartels A., Charlier B. (2015). Sources of dissolved 1126 silica to the fjords of northern Patagonia $\left(44-48^{\circ} \mathrm{S}\right)$ : the importance of volcanic ash soil 1127 distribution and weathering Earth Surf. Process. Landforms. DOI: 10.1002/esp.3840.

1128 Vanneste K., Wils K., Van Daele M. (2018). Probabilistic evaluation of fault sources based on 1129 paleoseismic evidence from mass-transport deposits: The example of Aysén Fjord, Chile. 
Journal of Geophysical Research: Solid Earth 123, 9842-9865. https://doi.org/10.1029/2018JB016289.

1132 Villalba R. (1994). Tree-ring and glacial evidence for the Medieval Warm Epoch and the Little 1133 Ice Age in Southern South America. Climate Change 26, 183-197.

1134 Villalba R., Leiva J.C., Rubulis S., Suarez J., Lenzano L. (1990). Climate Tree-rings and Glacial 1135 Fluctuations in the Rio Frias Valley, Rio Negro, Argentina, Arctic and Alpine Research 1136 22(3), 215-232. https://doi.org/10.1080/00040851.1990.12002786

1137 Villalba R., Boninsegna J.A., Veblen T.T., Schmelter A., Rubulis S. (1997). Recent trends in 1138 tree-rings records from high elevation sites in the Andes of Northern Patagonia. Climatic 1139 Change 36, 425-454.

1140 Villalba R., Lara A., Boninsegna J.A. et al. (2003). Large-scale temperature changes across the 1141 southern Andes: 20th-century variations in the context of the past 400 years. In: Climatic 1142 change climate variability and change in high elevation regions: Past, Present and Future, 1143 25-28 June 2001, vol 59. Davos, Switzerland, 177-232.

1144 Villa-Martínez R., Villagrán C., Jenny B. (2003). The last 7500 cal yr BP of westerly rainfall 1145 in Central Chile inferred from a high-resolution pollen record from Laguna Aculeo $\left(34^{\circ} \mathrm{S}\right)$. 1146 Quaternary Research 60, 284-293. doi: 10.1016/j.yqres.2003.07.007.

1147 Villa-Martínez, R., Moreno, P.I (2007). Pollen evidence for variations in the southern margin 1148 of the westerly winds in SW Patagonia over the last 12,600 years. Quaternary Research 68, 1149 400-409. doi: 10.1016/j.yqres.2007.07.003.

1150 Villa-Martínez R., Moreno P.I., Valenzuela M.A. (2012). Deglacial and postglacial vegetation 1151 changes on the eastern slopes of the Patagonian Andes $\left(47^{\circ} \mathrm{S}\right)$. Quaternary Science Reviews $1152 \quad 32,86-99$.

1153 Waldmann N., Anselmetti F.S., Ariztegui D., Austin J.A., Pirouz M., Moy C.M., Dunbar R. 1154 (2011). Holocene mass-wasting events in Lago Fagnano, Tierra del Fuego (54 ${ }^{\circ}$ ): 
1155 implications for paleoseismicity of the Magallanes-Fagnano transform fault. Basin Research 115623 (2), 171-190. DOI: 10.1111/j.1365-2117.2010.00489.

1157 Wei T. and Simko V. (2017). R package "corrplot": Visualization of a Correlation Matrix 1158 (Version 0.84). Available from https://github.com/taiyun/corrplot.

1159 Żarczyński M., Tylmann W., Goslar T. (2018). Multiple varve chronologies for the last 11602000 years from the sediments of Lake Żabińskie (northeastern Poland) - comparison of 1161 strategies for varve counting and uncertainty estimations. Quat. Geochronol. $1162 \quad 47,107-119$. https://doi.org/10.1016/j.quageo.2018.06.001.

1163 Zolitschka B. (1996). High resolution lacustrine sediments and their potential for palaeoclimatic 1164 reconstruction. In: Jones, Bradley and Jouzel (Eds), Climatic variations and forcing 1165 mechanisms of the last 2000 years. NATO ASI series 141, 453-478.

1166 Zolitschka B., Fey M., Janssen S., Maidana N., Mayr C., Wulf S. 1167 Haberzettl T., Corbella H., Lücke A., Ohlendorf C. and Schäbitz F. (2019). Southern 1168 Hemispheric Westerlies control sedimentary processes of Laguna Azul (south-eastern 1169 Patagonia, Argentina). The Holocene 29(3), 403-420. 


\section{Figure captions}

1172 Figure 1. (A) Location of Lake Jeinimeni within the Aysén region of Chile. The location of the 1173 Hudson volcano is reported on the map. (B) Simplified map of the regional geology, showing 1174 the North Patagonian batholith, the Eastern Andean metamorphic complex and the Late 1175 Jurassic volcano-sedimentary Ibañez Formation (Pankhurst et al. 1999). NPI: Northern 1176 Patagonian Ice Sheet, LGC/BA: Lago General Carrera/Buenos Aires. Lake Jeinimeni 1177 watershed is marked by a blue contour. (C) A lake watershed DEM (Digital Elevation 1178 Model) showing the main geomorphological features. The lake water body is reported in blue. (D) Map of basic bathymetric measurements and coring site, reported as a red dot, at 1180 the northern sector of Lake Jeinimeni. Images C and D, modified from Google Earth (C) 2019.

Figure 2. Core image, simplified lithological column with the event layers depths and major measurements, which include: $\mathrm{GL}=\mathrm{X}$-ray grayscale, $\mathrm{Al}$ counts, $\mathrm{MS}=$ magnetic susceptibility, water (LOI60) and organic matter content (LOI550), carbon/nitrogen atomic ratio $(\mathrm{C} / \mathrm{N})$ and carbon stable isotope $\left(\delta^{13} \mathrm{C}\right)$ measurements of core LJe14B. The simplified lithological column indicates the positions of 17 event layers, noted E1 to E17, which interrupt the background sedimentation. The three types of events are plotted with different symbols: the thickest and coarsest layers with erosive base in brown; the coarse layers without any erosion in black; the questionable layer resulting from cracks and sediment deformation in pale brown. E1 at $4.5-5 \mathrm{~cm}$ and E2 at 7.4-7.9 $\mathrm{cm}$ correspond to two tephras layers. B) Images illustrating the background sedimentation and different event types. The scale of each picture is approx. $20 \mathrm{~mm}$. Note the reported MS curve represents an average of three profiles.

Figure 3 - On the left panel, Electron Microprobe (EMPA) characterisation of glass shards extracted from E1 and E2 event layers in core LJe14B. All the analysed glasses fit with the field of the High Abundance Magma Field of the eruptive products from the Southern Volcanic Zone (SVZ) as reported in Stern et al. (2015). Moreover, the glass chemistry is 
consistent with the signature of the Hudson 1991 eruption (data from Naranjo and Stern 2004). On the right panel, Scanning Electron Microscope photographs and elemental EDX composition of representative glassy samples with circular or elongated gas bubbles: A. E1 4.5-5 cm, B - E2 7.4-7.9 cm. The EDX major chemistry of the observed glasses from both E1 and E2 layer is consistent with a plagioclase composition.

Figure 4. Age model for the upper $16 \mathrm{~cm}$ of core LJe14B. A. Comparison between the agedepth model derived from varve counting and its uncertainty reported as black lines and the age-depth model based on ${ }^{137} \mathrm{Cs}$ and excess ${ }^{210} \mathrm{~Pb}$ data and its uncertainty marked as blue lines. For varve counting, maximum age takes in account all varves, minimum age does not include uncertain varves and mean age represents the half of uncertain varves added to chronology. The grey bars indicate events E1 and E2 correspond to the two Hudson eruptions of 1991 and 1971 AD, respectively. B. The curve corresponds to the exponential fit of the ${ }^{210} \mathrm{~Pb}_{\mathrm{xs}}$ decrease. Note the two uppermost samples $(0-1 \mathrm{~cm}$ and $2-3 \mathrm{~cm})$ and the sample at 7$8 \mathrm{~cm}$ (tephra E2) were excluded from the age model since they present no or low ${ }^{210} \mathrm{~Pb}_{\mathrm{xs}}$. The age model derived from ${ }^{137} \mathrm{Cs}$ and excess ${ }^{210} \mathrm{~Pb}$ activities (B) is elaborated by linear interpolation with Clam 2.2 code (Blaauw 2010a,b). C. Age model for core LJe14B as derived from varve counting. The events labelled E1 to E17 are marked. The enclosed photo gives an example of the laminated sediment texture, with an alternation of thicker quartz and feldspar-rich coarse-grained lamina and thinner fine-grained lamina.

Figure 5. PCA biplot of XRF core scanner dataset (except Mn) reported as a binary diagram of the first two principle components PC1 and PC2. The samples are reported with different symbols according to their dominant lithology. This diagram emphasizes the distribution of the samples in 4 groups according to their lithology. The three groups distributed along the PC1 axis correspond to sedimentary samples dominated by fine-grained lamina (red diamond), coarse-grained lamina (blue circle), and the massive, sandy to gravely, event E3, 
E4 and E7 (open blue square). The fourth group plots along the PC2 axis and corresponds to the tephra (dark grey triangle) and tephra-influenced (light grey triangle) layer.

Figure 6. A. Selected sedimentological and geochemical data of LJe14B reported vs. depth, i.e., PC1 and PC2 scores, and varve thickness in $\mathrm{mm}$ ) The reported numbers correspond to the event layers observed in the core sedimentary features. B. Varve thickness is also reported vs. varve number (upper horizontal axis) and varve age model (lower horizontal axis) for comparison. The bold line represents a 5-years moving average curve. The horizontal bar underlines the interval characterized by the thickest varves. Its estimated age ca. AD 1750 is consistent with the oldest limit of the LIA-type event in North Patagonia, as reported by maximal and minimal extension of the Glacier San Rafael (GSR) in the Laguna San Rafael (Araneda et al., 2007). See text for more explanation.

Figure 7. Comparison of the varve thickness evolution of Lake Jeinimeni LJe14B with some regional records from lacustrine and glacial archives. (a) Varve thickness sequence back to AD 1530 obtained from the short core PUII of Lago Puyehue $\left(40^{\circ} \mathrm{S}\right)$ by Boës and Fagel (2008). The varve thickness has been correlated to precipitation, the highest correlation being obtained for May, i.e. autumn/winter transition. The grey line represents the annual variations of the varve thickness, the dark grey line the 5-year filtered record and, the dashed black line the 30-year filtered. (b) Evolution of varve thickness of LJe14B for the last 500 years. The grey line represents the annual variations of the varve thickness, the black line the 10-year filtered record. (c) Reconstruction of austral winter (JJA) precipitation for varved sediments of Lago Plomo (46 $\left.59^{\prime} \mathrm{S}\right)$ derived from mass accumulation rate back to AD 1530. The thin black line represents 5-year filtered precipitation data. The dashed line shows the 30 years filtered reconstruction. (d) Variations of tree-ring index on Nothojagus pumilio over the last 500 years (Villalba et al., 1990). The formation of wider tree-rings has been correlated to cold and rainy summers and to Glacial Frias re-advances. On the curve, the 
black arrows indicate the position of the Glacier Frias advances, their thickness being indicative of the event extension. Note all the curves indicate higher precipitation upwards. The location of the different records cited in the text is reported on the adjacent map on the right side of the figure. See text for more explanation.

\section{Table captions}

Table 1. Measured activities of ${ }^{210} \mathrm{~Pb} \mathrm{xs},{ }^{232} \mathrm{Th}$ and ${ }^{137} \mathrm{Cs}$ in sediment samples of the uppermost $16 \mathrm{~cm}$ of core LJe14B.

Table 2. AMS radiocarbon ages obtained on bulk sediment samples. An age reservoir correction of 540 years was applied taking in account a $\mathrm{C} / \mathrm{N}$ ratio of 16.7 (\% at.) following the equation proposed by Bertrand et al. (2012). Four intervals (4.5-4.9, 34-39 cm, 44-48 cm, 65-67 cm) were considered as events and were removed for the calibration. Radiocarbon dates were calibrated by Clam calibration program (Blauw et al., $2010 \mathrm{a}, \mathrm{b}$ ) using atmospheric SHCal13 calibration curve (Hogg et al., 2013). Samples were measured at the Gadam Radiocarbon Laboratory.

Table 3. Results of principal component analysis (PCA) on raw XRF core scanner dataset. The table gives the contribution of each principal component in total variance. PCA was performed without Mn because its communality value was lower than 0.5 .

Table 4. Calibration of varve thickness and geochemical data (principal components PC1 and PC2, Si/Al) with CRU-TS reconstruction over 1930-1988 AD. Meteorological data retrieved from National Center for Atmospheric Research Staff (2017). Statistically significant correlations, according to Pearson's correlation coefficient with $\mathrm{p}$-value $<0.05$, are reported in color (positive in red, negative in blue). The number of asterisks gives the degree of significance: ${ }^{*} \mathrm{p}<0.01,{ }^{* *} \mathrm{p}<0.001$ and ${ }^{* * *} \mathrm{p}<0.0001$. Note the same correlations are observed for averaged or accumulated precipitation. 
Table 5. Overview of regional paleoenvironmental information deduced from published climate archives reported over a $20^{\circ}$ latitudinal transect from $33^{\circ}$ to $53^{\circ} \mathrm{S}$ in South America.

\section{Supplementary material}

SM Figure 1. XRD mineralogy on bulk sediment. The sample are reported along the $\mathrm{x}$-axis. Each sample correspond to $1 \mathrm{~cm}$ of sediment thickness and the label represents the middepth of the sample expressed in $\mathrm{cm}$. The $\mathrm{T}$ at the end of the label indicates the two tephra layers. The cumulated mineral abundance is given along the y-axis. Each mineral is represented by a distinct color, the color code being given on the right site of the diagram. $\mathrm{OM}$ corresponds to the organic matter deduced from the loss-of-ignition at $550^{\circ} \mathrm{C}$ (LOI550). OM abundance was removed from the XRD-estimated total amorphous content in the sediments (i.e., sum of biogenic silica, volcanic glasses and/or organic matter).

SM Figure 2. XRF core scanner elemental profile for Si, K, S, Ca, Sr, Rb and Zr.

SM Figure 3. Grain-size distribution measured by a laser Malvern ${ }^{\circledR}$ Mastersizer 2000 diffraction particle analyser. The selected samples correspond to different event layers, evidenced by macroscopic description. The samples are identified by their depth interval expressed in $\mathrm{cm}$. Note the three samples characterize by the highest abundance of coarse sand grains (i.e. samples 35-36, 44-45 and 65-66) correspond to the coarsest layers E3, E4 and E7. The samples 4-5 and 7-8 corresponding to the tephra layers E1 and E2 display a broad range of grain size with a clear influence of the fine background sedimentation.

SM Figure 4. Age model for core LJe14B derived from ${ }^{210} \mathrm{~Pb}-{ }^{137} \mathrm{Cs}$ data (data in Table 1) and AMS radiocarbon dates on bulk sediment (data in Table 2). The linear interpolation between the dated samples does not take into account the observed event layers (i.e., E1 4-4.5 cm, E2 7.4-7.9 cm, E3 $35-36 \mathrm{~cm}, \mathrm{E} 444-45 \mathrm{~cm}$ and, E7 $65-66 \mathrm{~cm}$ ), marked by the horizontal grey 
1295 bars. The dashed red line corresponds to an extrapolation of the sedimentation rate measured 1296 for the upper16 $\mathrm{cm}$ of core LJe14B and consistent with varve counting.

1297 SM Figure 5. Correlation between local meteorological data (i.e., precipitation, temperature) 1298 retrieved from Instituto de Investigaciones Agropecuaria (INIA - Hepp et al., 2018) and 1299 sedimentological (varve thickness) or selected geochemical proxies of LJe14B discussed in 1300 the text (PC1 and PC2 scores, Si/Al). All curves correspond to a 7-years moving average. $1301 \quad$ Data from Table 4. 